\title{
How Does Corruption Affect Economic Growth? An Econometric Analysis
}

\author{
N N Tarun Chakravorty \\ Siberian Federal University
}

This paper investigates the growth-corruption link in a non-linear relationship in interaction with freedom status, recruitment quality and openness of the economy, and looks into the impact of corruption using cross-sectional and panel data. Examining the growth-corruption link in interaction with recruitment quality is new in the literature. A rigorous econometric exercise has been done to conduct the investigation and various techniques have been applied to have robust results. It is found that corruption exerts a positive but small impact on economic growth, which varies with changes in freedom status, executive recruitment quality and openness of the economy.

Keywords: Corruption, Economic Growth, Freedom, Recruitment Quality

\section{INTRODUCTION}

Institution and governance factors have long been seen to affect economic growth and development (Myrdal, 1968; La Porta et al., 1999; Shleifer and Vishny, 1993; North, 1981; De Long and Shleifer, 1993; Knack and Keefer, 1995; Easterly and Levine, 1997; Acemoglu and Verdier, 1998; Kaufmann and Kraay, 2003; Méon and Sekkat, 2005; Acemoglu and Johnson, 2005; Aidt, Dutta and Sena, 2008; Huang and Ho, 2017). The effect of corruption which is a governance factor, however, is not clear-cut. Some studies find corruption to affect growth negatively (Rose-Ackerman, 1978; Mauro, 1995; Brunetti, Kisunko and Weder, 1998; Mo, 2001; Gould and Amaro-Reyes, 1983; Klitgaard and Klitgaard, 1991; Murphy et al., 1990; Knack and Keefer, 1995; Davoodi and Tanzi, 2002; Kaufmann and Wei, 1999; Gyimah-Brempong, 2002; Campos, Dimova and Saleh, 2010; Nguyen and Van Dijk, 2012; Ugur, 2014; Kumi et al., 2015) while many have found corruption to help economies to grow ((Leff, 1964; Huntington, 1968; Lui, 1985; Leys, 1965; Bayley, 1966; Khan, 2006; Morgan, 1964; Mankiw, 2000; Méon and Sekkat, 2005; Méon and Weill, 2010). Recently, some studies came up with the view that the effect of corruption is indeterminate (Hall and Jones, 1999; Kaufmann et al., 2002; Wedeman, 1997). This view is strengthened by Shaw et al. (2011)'s re-examination of Mauro (1995)'s work with better econometric tools, which finds no effect of corruption on economic growth or investment. This ambiguity in the effect of corruption demonstrtates the need for new investigations on different perspectives with better research tools addressing the possible imperfections in the existing studies despite a huge body of work being already available in this area.

In recent studies, corruption has been seen to affect growth via other variables. In other words, the impact of corruption on growth is found to vary with differences in transmission channels such as investment, human capital, political instability (Mo, 2001), trade openness (Pellegrini \& Gerlagh, 2004), 
regional characteristics, inequality in land distribution (Mishra, 2010), bad loans (Park, 2012), tax evasion (Cerqueti \& Coppier, 2011), gross fixed capital formation and labour force (Kumi et al., 2015). The fact that the impact of corruption on growth might be influenced by other variables such as political freedom (Méndez and Sepúlveda, 2006; Aidt et al., 2008), democracy (Drury et al., 2006; Chowdhury, 2004; Rivera-Batiz, 2002) indicates a non-linear relationship between corruption and growth, and hence, investgating this relationship in a nonliear econometric equation has been predominant in the literature lately.

Among all those transmission chanels mentioned above, freedom status and recruitment quality being two important elements of democracy, have been considered important because, although many studies such as (Dreze and Sen, 1989; Boix, 2001; Lake and Baum, 2001; Brown and Mobarak, 2009; Saha and Zhang, 2017) find democracy to exert a positive effect on economic growth, in reality corruption situation is seen to persist and economic growth is seen to remain slow even after democratic transition of many countris.

The novelty of my paper lies in that it has investigated the growth-corruption link in interaction with executive recruitment quality. Also, the technique of investigating the influence of freedom status in this paper, is different from Méndez and Sepúlveda (2006) which, to the best of my knowledge, is the only study examining the relationship between corruption and economic growth with respect to freedom status. The similar studies which have examined the influence of the components of democracy on the growthcorruption link, have mostly used fress freedom (not overall freedom) and civic rights.

This cross-country study has been carried out using two datasets: first, a cross-section of 119 countries using averages over 2000-2011 and second, a panel dataset over 1985-2013. I used both CPI (constructed by Transparency International) and ICRG index (constructed by the PRS group) as measures of corruption for this impact study. In several instances, the panel data model provides more efficient estimations and for me, it has also worked as a robustness check of the results obtained from the crosssection analysis. From both cross-country and panel data analyses, corruption is seen to have a positive but small impact on economic growth. This study adds to the existing body of work by examining the effects of corruption on growth by interacting it with executive recruitment quality. I have analysed the average marginal effect of explanatory variables on the estimated growth with respect to corruption, freedom status, executive recruitment quality and their interactions. Evidence is found that the effect of corruption varies when the freedom status changes from below average to above average and when executive recruitment quality changes from below average to above average.

\section{BACKGROUND AND EXISTING LITERATURE}

Dawson (2003) has examined the causal relationship between growth, investment and press freedom, overall freedom. He finds that changes in and levels of freedom are jointly determined with growth and that overall level of economic freedom causes economic growth to rise. In this paper it is also seen that changes and levels in the broad measure of freedom determine the level of investment. Greater freedom leads to higher level of investment. When the main components of political freedom i.e. political liberties and civil liberties are included in the analysis, they are seen to have significant positive impact on economic growth but not on investment. Institutions, governance regime and freedom have been seen to affect both corruption and growth (Aidt et al. 2008; Chowdhury 2004; Drury et al. 2006; Rivera-Batiz 2002). In particular, Vega-Gordillo and Alvarez-Arce (2003) and Brunetti and Weder (2003) have found a clear positive impact of press freedom on economic growth.

Méndez and Sepúlveda (2006) and Aidt, et al. (2008) have found that relationship between corruption and growth is nonlinear in an equation where political freedom has been the cause of this non-linearity. That is, the effect of corruption does not fall on growth linearly rather via freedom. Méndez and Sepúlveda (2006) in their study have divided the sample between free and not-free countries and found distinction in the effect of corruption between countries free and countries not-free. Corruption is seen to have positive impact on growth only in free countries in their study. Swaleheen (2011) uses a panel dataset of countries and performs GMM estimation on a non-linear model, who finds corruption to have a 
negative impact on growth. However, this negative impact is not found in all levels of corruption. In a sub-sample of countries having high levels of corruption, corruption is seen to augment growth. Fayissa and Nsiah (2013) taking data from 39 Sub-Saharan African countries finds a nonlinear relation between governance and economic growth and that the role of governance in determining economic growth depends on the level of income.

While Cooray (2009), Kaufmann, Kraay and Zoido-Lobatón (1999) examined the impact of governance, quality of government on growth and income per capita, and found it to be positive, many others have examined the impact of the various components of composite governance indicator. Dollar and Kraay (2002) and Rigobon and Rodrik (2005) who have examined the effect of rule of law, found a significant positive effect on economic growth. De Groot et al. (2004) find regulatory quality to have a positive effect on both trade and economic growth in democratic countries. The study by Jalilian, Kirkpatrick and Parker (2006) suggests a significant positive impact of regulatory quality and government effectiveness (two components of WGI) on the GDP per capita in developing countries. María-Teresa et al. (2012) examine the effect of four component indicators of WGI, namely voice \& accountability, government effectiveness, rule of law and control of corruption and find each of these indicators to impact economic growth positively. Huynh and Jacho-Chávez (2009) examine political stability, government effectiveness, and rule of law with respect to economic growth and find them affecting growth positively. Gani (2011) examines the association between economic growth and political stability and government effectiveness in developing countries and finds significant positive correlations. However, in the same study voice \& accountability and control of corruption are seen to have significant negative effect, and regulatory quality and rule of law are also seen to have negative but insignificant correlations with economic growth in developing countries. Acemoglu and Robinson (2012) argue that inclusive economic institutions can emerge and encourage growth in the short run but cannot survive in the long run in a nondemocratic regime.

Huang and Ho (2017) investigates the causal relations of the components of Worldwide Governance Indicators (WGI) and WGI itself with economic growth over the period of 1996-2014 for 12 Asian countries (Cambodia, Indonesia, Laos, Malaysia, Philippines, Singapore, Thailand, Vietnam, Taiwan, China, Japan and South Korea) dividing them into 'free', 'partly free' and 'not free' groups using frequency domain Granger causality test in VAR model. Findings are mixed: all the components of the governance index do not affect economic growth for the all the countries. It is, therefore, difficult to make inferences on the effect of these component indicators on economic growth. Only rule of law as a dimension of governance has been seen to affect economic growth among all twelve countries, and government effectiveness and rule of law are seen lead to more significant economic growth in 'Not Free' countries when compared to 'Free' and 'Partly Free' countries. As regards to causality running from economic growth to governance, the authors have seen that economic growth influences some components of the governance indicator (WGI) for some countries out of the 12 Asian countries mentioned above, for example, voice and accountability for China and Laos, political stability in Indonesia, Singapore, Cambodia, and Laos, government effectiveness for Philippine and Thailand, regulatory quality for Taiwan, Indonesia, Singapore, China, and Laos, rule of law for 8 of these twelve countries except Japan, South Korea, Malaysia, and Singapore; control of corruption for South Korea, Taiwan, Singapore, Cambodia, and Vietnam. They have found two-way causality between economic growth and some components of the governance indicator, namely voice \& accountability, political stability, regulatory quality, rule of law and control of corruption.

Recent studies find deep historical differences in institutional quality to be the cause of current wide gaps in per capita incomes across countries. Given current differences in institutional performance is isolated, initial (200 years ago) institutional quality is seen to exert a powerful effect on growth in the very long run (Kaufmann \& Kraay, 2003). Kaufmann and Kraay (2003) in their methodology separate out the effects of per capita incomes on governance and find the reverse causality to be negative and warn that there is no possibility of 'virtuous circles' i.e. automatic improvements in governance is unlikely to happen following rises in per capita income. 
Ben Ali and Saha (2016) examine the development-corruption link for a set of Middle Eastern and North African countries and find a nonlinear relationship. At a low level of economic development, as they find, growth in per capita income could increase corruption, but after a threshold level of income, an increase in income is seen to lower corruption.

The relationship between democracy and income per capita and development has been empirically investigated widely in Economics - mainly in Political Economy (Acemoglu et al., 2008). Starting from North (1990), in many other later studies such as Butkiewicz and Yanikkaya (2006), Djezou (2014), Nawaz (2015) democratic institutions likewise governance have been found to be a determining factor of economic growth. Some recent studies (e.g. Rodrik and Wacziarg, 2005; Papaioannou and Siourounis, 2008; Persson and Tabellini, 2009; Heid et al., 2012; Benhabib et al., 2013) confirm the positive effect of democracy on economic growth. Alongside, studies like Shandra et al. (2004), Ross (2006), Acemoglu et al. (2008) find no positive correlation between regime type i.e. democratic or autocratic government and human development as against the popular view that democracy promotes human development, supported by studies like Lipset (1959), Meltzer and Richard (1981), Dreze and Sen (1989), Boix (2001), Lake and Baum (2001), Brown and Mobarak (2009). Some East Asian non-communist countries such as Singapore are seen to have achieved spectacular development under the authoritarian rule (Gerring et al. 2012). Narayan et al. (2011)'s econometric analysis shows evidence from the Sub-Saharan African countries that in the long run democracy Granger causes real income and an increase in democracy has a positive effect on real income only in a few countries, and there is long run Granger neutrality between democracy and real GDP in most countries. Saha \& Zhang (2017) find a nonlinear relationship between democracy and human development. In their study, democracy appears to be a stronger driver for improving human development than income per capita growth does.

Even after the application of sophisticated econometric tools, the effect of corruption on economic growth has remained debatable i.e. the results from various studies on this issue are mixed in the literature. The main thrust of Bologna (2018) is to investigate the cause of the variations in the results and examines the corruption-growth link incorporating in the regression uncertainty surrounding bribe payments - uncertainty regarding the success of the bribe. From World Bank's World Business Environment Survey, he takes the average firm response to the question, "If a firm pays the required 'additional payments' the service is usually also delivered as agreed" as an average corruption uncertainty measure for a country. His rigorous experiments using interaction terms consisting of corruption experience, uncertainty and economic freedom do not reject the hypothesis that failing to capture the effect of the level of uncertainty involved in bribery is responsible for mixed results of the effect of corruption. Precisely, at very low levels of uncertainty, bribery is found to exert a positive effect on growth and after a certain level of uncertainty is crossed, bribery starts affecting growth negatively.

The studies discussed above built my perception that corruption must impact economic growth either negatively or positively and that the amount of this impact may be partly determined by institutional/governance and political factors i.e. the relationship between corruption and growth may be non-linear.

\section{METHODOLOGY}

To quantify the impact of corruption on macroeconomic growth a quantitative analysis has been carried out in this study. In the first stage, averaging the response variable i.e. GDP per capita growth, main variable of interest which is corruption and some other control variables over 2000-2011 a typical estimation procedure for cross-country analysis has been followed. This cross-country analysis has not provided me with impressive results. In the simple OLS regression, the coefficient of the variable of interest i.e. corruption has been significant, but it is suspected to suffer from the problems of endogeneity and heterogeneity. One of the main reasons for the possible problems of endogeneity and heterogeneity is the fact that growth equations, as argued by Caselli et al. (1996), are characterized by dynamics and endogenous regressors. OLS estimator applied on these, therefore, would not be appropriate. To overcome the problem of endogeneity, Instrumental Variable (IV) technique is used but since the 
instruments used are found to be weak and no other instrument is available, results from the IV are not impressive. The coefficient of the variable of interest is not satisfactorily significant. Besides the problems of heterogeneity and endogeneity, there may be arbitrarily distributed fixed individual effects which would fall on all observations inflating or deflating the effect of corruption.

Because of the virtues of the panel data and for some desirable features many econometricians and authors suggest panel data model. For example, according to Arellano and Bond (1991), a dynamic panel General Method of Moments (GMM) estimator optimally exploits the linear moment restriction simplified by the dynamic panel growth equation. Accordingly, to overcome the short-comings of the OLS and IV estimators of the cross-section dataset, in other words, to address the problems of heterogeneity and endogeneity, in the second stage, a panel dataset over 1996-2013 has been used, and Fixed Effect estimator and GMM estimator have been applied. In panel approach the estimation does not impose that $\mu_{i}$ and $x_{i t}$ are uncorrelated; a panel approach is, therefore, expected to provide us with efficient and consistent estimates. Estimates have been done based on levels, first difference and on orthogonal deviations. GMM applied on the panel where variations over time can be used to identify parameters, would remove individual effect (Roodman, 2012).

\section{MODEL SPECIFICATION}

The assumption of independence of regressors is plausible but may not always be appropriate. For example, impact of corruption and freedom status or recruitment quality on growth is not merely additive; rather, their impact is more than the sum of their individual effects. As Méndez and Sepúlveda (2006) and Aidt, et al. (2008) have found that relationship between corruption and growth is nonlinear in an equation where political freedom has been the cause of this non-linearity. In means that corruption impacts growth differently in countries with different degrees of political freedom given all other factors constant. If the relationship is not nonlinear, in particular, if the degree of political freedom is the same across countries, then growth would increase at the same rate as corruption increases but when the relationship is nonlinear, in our present case due to varying degree of political freedom, growth would increase at higher rates with the same rate of increase in corruption but with higher degree of political freedom. It means that the impact of corruption and freedom together on growth is more than the sum of their individual effects. Democracy is also found to influence the magnitude of the impact of corruption on growth (Drury et al. 2006; Aidt et al. 2008; Chowdhury 2004; Rivera-Batiz 2002). The fact that the degree of competition in executive recruitment is one of the components that constitute the democracy variable motivated me to hypothesize that executive recruitment quality itself would influence the magnitude of the impact of corruption on growth. In the same way, as corruption and freedom, corruption and executive recruitment quality together would have effects on growth, which is more than the sum of their individual effects. In such a case, interaction effects need to be allowed to take place in evaluating how these variables exert impact together. Interactions allow such effects to be correlated (Baum \& Christopher, 2006). In the simple OLS, therefore, besides the individual use of a number of independent variables, the impact of these variables on growth has also been examined by putting the main variable of interest which is corruption in interaction with freedom status and executive recruitment quality both as continuous and categorical variables. It has been done because here the main interest is to see if freedom status and executive recruitment quality influence how corruption affects growth rather than seeing their individual effects only. With this end, two interaction terms are included in the regression model.

The theoretical model that underlies the regression estimation and the model specified is based on Barro (1991), popularly known as 'Barro Cross-Country Regression Framework' which, in turn, is based on the extended version (such as Lucas (1988); Romer (1990); Becker et al. (1994)) of Solow neoclassical growth model. The extended version of neoclassical growth model incorporates human capital and allows for international mobility of capital and technology. The regression model used in the cross-country analysis on the impact of corruption on macroeconomic growth here is, however, further augmented over Barro (1991) by including some governance variable following Mauro (1995). 
The model regressing economic growth on corruption along with the relevant control variables takes the following form:

$y_{i}=\beta_{0}+\beta_{1} b_{i}+\beta_{2} G_{i}+\beta_{3} I_{i}+\beta_{4} C_{i}+\beta_{5} H_{i}+\beta_{7} P_{i}+\beta_{8} A_{i}+\beta_{9} F_{i}+\beta_{10} E_{i}+\beta_{11}\left(b_{i} \# F_{i}\right)+$ $\beta_{12}\left(b_{i} \# E_{i}\right)+e_{i}$

where $y$ is the average of the growth rates over 2000-2011, $b$ is a measure of corruption, $G$ is GDP per capita in 2000, $I$ is gross domestic investment as a percentage of GDP, $C$ is gross government consumption expenditure as a percentage of GDP, $H$ is a measure of human capital in $2000, P$ is the population growth rate and $A$ is Development assistance and aid, $E$ is executive recruitment quality, $F$ is the freedom status, $b \# F$ and $b \# E$ are interaction terms created between corruption and freedom status, and interaction term between corruption and executive recruitment quality respectively, $e$ is the error term. The index used with the variables indicate the individual countries (i.e. $i=1,2, \ldots . ., \mathrm{N}$ ). The overall impact of corruption is then:

$$
\left(\beta_{1}+\beta_{11} F_{i}+\beta_{12} E_{i}\right) b_{i}
$$

For the regression estimation on the panel data, the model has been specified in the following form:

$y_{i t}=\alpha y_{i, t-1}+X_{i t}^{\prime} \beta+\varepsilon_{i t}$

Here $y_{i t}$ being a growth variable which has two indices: $i$ indicates the individual countries (i.e. $i=1,2$, $\ldots \ldots, \mathrm{N}$ ) while $t$ indicates different time periods (i.e. $t=1,2, \ldots \ldots, \mathrm{T})$. In the panel model a lagged dependent variable has been entered $\left(y_{i, t-1}\right) . X$ is a vector of a number of explanatory variables affecting growth: corruption, investment, government consumption, literacy rate, population growth rate, quality of human capital, openness.

In affecting growth, corruption might not depend on its own value only. It might also depend on other variable (s). In this analysis of the impact of corruption on macroeconomic growth, it has been suspected that the extent to which corruption affects growth might depend on how much the economy is open i.e. how much the country is engaged in export and import. From this argument, an interaction term named 'interaction' consisting of corruption and openness i.e. corruption\#openness has been used in the regression to capture this effect while openness of a country has been measured by (export/GDP + import/GDP). Being motivated by the possibility of their exponential effect some variables have been used as their squared terms as well as the levels. These are corruption-squared, openness-squared and interaction-squared. Including all the variables discussed above the regression equation takes the following form:

$y_{i t}=\beta_{0}+\alpha y_{i, t-1}+\beta_{1} b_{i t}+\beta_{2} I_{i t}+\beta_{3} C_{i t}+\beta_{4} H_{i t}+\beta_{5} L_{i t}+\beta_{6} P_{i t}+\beta_{7} b s q_{i t}+\beta_{8} O_{i t}+\beta_{9} O s q_{i t}+$

$\beta_{10}\left(b_{i t} \# O_{i t}\right)+\beta_{11}\left[\left(b_{i t} \# O_{i t}\right) s q\right]+\varepsilon_{i}$

where $b, I, C, H, L, P, b s q, O, O s q, b_{i t} \# O_{i t},\left(b_{i t} \# O_{i t}\right) s q$ are corruption, investment, government consumption, quality of human capital, literacy rate, population growth rate, corruption-squared, openness, openness-squared, interaction term of corruption and openness, square of the interaction term of corruption and openness respectively.

In equation (3) the disturbance term has two orthogonal components: the fixed effects, $\mu_{i}$ and the idiosyncratic shocks, $v_{i t}$ i.e.

$\varepsilon_{i t}=\mu_{i}+v_{i t}$ 
$\mu_{i}=$ are unobserved individual level effects which are time invariant and homoskedastic across individuals.

$v_{i t}=$ are observation-specific errors

\section{ESTIMATION TECHNIQUES}

The estimations were started with standard OLS regression and then to address the endogeneity problems Instrumental Variable (IV) method with 2sls has also been used.

The probability of multicollinearity, redundant variable, omitted variable, heterogeneity have been checked with VIF test, t test, Ramsey RESET Test, Breusch-Pagan/Cook-Weisberg test respectively. To check the joint significance F test has been applied. Breusch-Pagan / Cook-Weisberg test is done to check the suspected heterogeneity. To address the problem of possible heterogeneity in the features of countries, in other words, to prevent the estimates from being biased and inconsistent due to the possible correlations between errors, the OLS technique which is robust to heterogeneity has been used. Standard approach of using VCE (robust) option in Stata, provides standard errors which are valid even if model errors are heteroskedastic (Cameron \& Trivedi, 2009).

The fact that good economic performance might improve institutional efficiency and that corruption level of a country might be correlated with its economic and institutional factors, provides the sources of endogeneity bias in the estimator. To overcome this problem, Instrumental Variable (IV) method has been used, where an index of Ethnolinguistic Fractionalization (ELF) (which measures the probability that two persons drawn at random from a country's population will not belong to the same ethnolinguistic group) as an instrument for corruption. ELF index being correlated with the corruption index constructed for this analysis is expected to serve as a good instrument because it can be assumed to be exogenous both to economic variables and to institutional efficiency (Mauro 1995).

Robust score chi2 Test, Robust regression F Test, Wu-Hausman F test, Durbin-WuHausman chi-sq test and Hausman test are conducted to check the presence of endogeneity in the OLS regressions. Correlation between corruption and its instrument, ELF has been found, and 2SLS and LIML Wald test are conducted to assess the weakness of the instrument. The first-stage regression in IV has done Anderson-Rubin Wald F test, Anderson-Rubin Wald Chi-sq test and Stock-Wright LM S statistic Chi-sq test - which all have made weak-instrument-robust inference for me. ivreg2 command for running IV regression has automatically provided tests for under-identification test (Anderson canon corr. LM statistic) and over-identification test (Sargan statistic).

In the second stage of the analysis of the impact of corruption on macroeconomic growth, as has been mentioned earlier, a panel dataset has been used. For the panel data, both Fixed Effect (FE) estimator and GMM estimator have been used. Estimates in GMM have been done with system GMM, first difference GMM (first step and second step) and forward orthogonal GMM.

In FE model the problem of endogeneity caused by the correlation between the error term and one or more explanatory variables i.e. where the explanatory variables are not exogenous, is addressed by including an individual-specific intercept term in the model. It helps us in controlling for unobserved heterogeneity which is constant over time and correlated with dependent variables. In Fixed Effects estimator method regression is performed in deviations from individual means. Thus, this constant can be

removed from the data through differencing, for example, taking first difference will remove any time invariant components from the model. As a result, the individual effect which is captured by $\mu_{i}$ in equation (4) is eliminated. FE estimator, by first-differencing the equation, also removes the $v_{i}$ (see equation 4.)- thus eliminating a potential source of omitted variable bias (Verbeek, 2008; Roodman, 2012). But elimination of time-invariant components from the model by the Fixed Effects estimator might have been done at the expense of allowing the $X$ variables to be correlated with individual specific heterogeneity, which is $\mu_{i}$ in equation (4) (Verbeek 2008). For example, the impact of corruption on growth would not be singled out if different countries have different time-invariant variables such as the attitude of the members of the public towards life. Another problem with the fixed effects models is that they assume that the presence of $\mu_{i}$ (see equation 4) captures all correlation between unobservables in 
different time periods. That is, $v_{i t}$ (in equation 4) is assumed to be uncorrelated over individuals and time, but which is not true in case of a dynamic model where the true covariance matrix does have an error components structure. In this situation, Caselli et al. (1996) argue that the FE estimator is no longer appropriate and suggests that an instrumental variables (IV) estimator that produces consistent estimates in the presence of dynamics is needed. There are no reasonable instruments for the endogenous regressors that could be excluded from the growth equation used in the dynamic panel estimator. The only available instruments available are internal- based on lags of the instrumented variables. A dynamic panel General Method of Moments (GMM) estimator which uses internal instruments, is, therefore, then used in order to have consistent and efficient estimates.

A dynamic panel General Method of Moments (GMM) estimator optimally exploits the linear moment restrictions implied by the dynamic panel growth equation (Arellano and Bond 1991). The dynamic GMM panel estimator is an IV equivalent of an efficient Three Stage Least Squares (3SLS) estimator that uses all lagged values of endogenous and predetermined regressors as well as current and lagged values of strictly exogenous regressors as instruments in the differenced equation. These instruments are correlated with the endogenous regressors but not correlated with the error terms, hence they are good instruments. Estimates can be based on levels, first difference, or on orthogonal deviations (Roodman 2012).

As has already been mentioned, for the dynamic GMM panel estimator, instruments are drawn from within the dataset. The lagged values of the dependent variable of the levels or from the transformed data by differencing, are used as instruments, which would eventually provide us with levels estimator and difference estimator (Anderson \& Hsiao, 1982). As levels estimator is built on a system of two equations: the original equation and the transformed equation it is known as system GMM. Between levels estimator and difference estimator the levels estimator seems to be preferable to difference estimator because the latter decreases the sample size since the lagged value to be used as an instrument in this case would not be available until it is lagged by $t=4$. For the levels estimator an instrument would be available if $t$ is equal to just 2. Clearly, there appears to be a trade-off between lag length and sample length in the use of levels estimator and difference estimator. Working in the GMM framework, Holtz-Eakin et al. (1988) finds a way to get around this trade-off. Instead of entering the instrument, $y_{i, t-2}$ i.e. the second lagged value of the dependent variable into one column they build a set of instruments from the second lag of $y$, one for each time period and substitute zeros for missing observations. Instruments found in this way are 'GMM-style' instruments. These newly created columns of instruments are orthogonal to the transformed errors i.e. $E\left(y_{i, t-2} \varepsilon_{i t}^{*}\right)=0$ providing us with a consistent and efficient estimator. These instrument sets are part of what is called difference and system GMM (Roodman 2012). It offers the forward orthogonal deviation transform, an alternative to differencing proposed by Arellano and Bover (1995) that preserves sample size in panel gaps increasing a rise in accuracy. Forward orthogonal deviations or orthogonal deviations can remove the weakness of the first-difference transform which magnifies gaps in unbalanced panels (Roodman 2012).

The dynamic GMM involves two estimators- one-step estimator and two-step estimator. As was explained earlier, the presence of heterogeneity in $v_{i t}$, the observation-specific errors make the estimator inefficient. To overcome this inefficiency, differencing has been proposed but even after differencing, differenced $v_{i t}$ i.e. $\Delta v_{i t}$ may not be iid leading to a fall in accuracy. To prevent this fall in accuracy a GMM called orthogonal GMM proposed by Arellano and Bond (1991) as mentioned above, has been done. In orthogonal GMM estimator the covariance matrix of transformed errors is estimated twice in two steps: in the first step a priory estimate of the covariance matrix of errors is done arbitrarily; in the second stage, a proxy covariance matrix of transformed errors i.e. a matrix formed from the residuals of a preliminary consistent estimate is taken.

There are different views about which estimator between one-step and two-step is more appropriate. Two-step estimator is more efficient than the one-step estimator although both estimates will be asymptotically equivalent if and only if the error structure is spherical. However, it may be the case that the nature of the model with endogenous regressors and possible correlated fixed effects lead to the 
failure of the conditions for spherical error structure (Gyimah-Brempong, 2002). The failure of the conditions for spherical error structure means that errors would remain correlated with regressors making the one-step estimator inefficient. On the other hand, Arellano and Honore (1999) argue that in the absence of good instruments, the two-step estimator underestimates the standard errors of the coefficient estimates, hence providing inflated t-statistics. The one-step estimator is not subject to this kind of wrong t-statistics, hence may be more reliable than the two-step estimator. Both one-step and two-step estimates have been done in this regression analysis and compared.

The consistency of the estimates, hinges on the assumption of lack of autocorrelation of the error terms (Gyimah-Brempong 2002). Therefore, test for the absence of first-order serial correlation of the error terms has been conducted. Sargan test of over-identifying restrictions which is a joint test of model specification and appropriateness of the instrument vector has been conducted. If all regressors are strictly exogenous, both the dynamic panel estimator and the FE estimator are consistent but the latter is efficient. On the other hand, if there are endogenous explanatory variables, the FE estimator is inconsistent. I, therefore, use a Hausman test to test for the strict exogeneity of all regressors used in the growth equation.

\section{DATA, VARIABLES, MEASUREENT ISSUES AND ESTIMATION PROBLEM}

\section{Description of Data}

For the macroeconomic variables such as growth rate, GDP in 2000, investment, government consumption expenditure, population growth rate, teacher-pupil ratio, development assistance \& aid data have been downloaded from the World Bank website; for sampling and data collection methods (please visit http://datacatalog.worldbank.org/). For the measure of corruption CPI (Corruption Perception Index) data have been downloaded from the website of Transparency International (http://www.transparency.org/research/cpi/overview) and corruption index from the website of International Country Risk Guide (ICRG) (http://www.prsgroup.com/ICRG_methodology.aspx) and Ethnolinguistic Fractionalization (ELF) index data are taken from http://www.nsd.uib.no/macrodataguide/set.html?id=16\&sub=1. A number of studies have used ICRG and CPI indices as corruption measures: Herzfeld \& Weiss (2003) have used both ICRG and CPI, Alesina and Weder (1999) have used both ICRG and CPI, Svensson (2005) has used both ICRG and CPI. In favor of the use of these different measures of corruption in one analysis Alesina and Weder (1999) observe that all these indices, even though measured from slightly different angles, are highly correlated. These high correlations give us confidence in the measures of corruption. You and Khagram (2005) use the average of World Bank Institute's Control of Corruption Index (CCI) and the Transparency International's CPI and ICRG index. In the analysis done in this study an average of ICRG and CPI indices has been used as a measure of corruption. Since these indices are governance indicators, higher values of these indices show lower level of corruption.

Easterly and Levine (1997) find Ethno-Linguistic Fractionalization (ELF) to affect per capita GDP growth negatively. Canning and Fay (1993) and La Porta et al. (1999) have found ethnic fragmentation to have impact on growth through channels like public service delivery, quality of institution and so on while these channel variables are correlated with the level of corruption. The argument for using ELF for instrumenting corruption is that corruption level of a country has been found correlated with its ELF factor while it is not correlated with the unobservables determining the corruption level. To construct ELF index, first, an average of ethnic, religion and language indices is taken. Then it is computed as one minus the Herfindahl index of ethnolinguistic group shares. It reflects the probability that two randomly selected individuals from a population belonged to different groups. The formula used to compute ELF is:

$$
E L F_{j}=1-\sum_{i=1}^{N} s_{i j}^{2}
$$

where $s_{i j}$ is the share of group $i(i=1, \ldots, N)$ in country $j$ (Alesina et al.2003). 
Indices on freedom and executive recruitment quality data have been taken from the website of Freedom House International (http://www.systemicpeace.org/inscr/inscr.htm). Since 1970 Freedom House International, through conducting surveys on several countries, has recorded the state of several elements by which political rights index and civil liberties index are constructed. Then these two indices are used to construct the freedom index. To remove the possible endogeneity, the corruption variable has been instrumented also by ethnic, religion and language. Data for these variables are taken from Alesina et al. (2003).

The period of data for all the variables used in this study is 2000-2011. For all the variables (except $G D P$ and the quality of human capital) the averages of their values for 12 years have been taken. For these two (GDP and the quality of human capital), the figures in the initial year (2000) of the period of analysis are used. The number of countries for which data have been finally used has turned out to be 199 creating 199 observations in the set although there are more countries left out. Since data have been used from many sources, lists of countries vary from each other.

To construct the corruption variable CPI index and ICRG index have been averaged after bringing the both to the same scale ( 1 to 10 where $1=$ highest corruption and $10=$ no corruption). Freedom Index has been constructed by taking the average of political rights and civil liberties indices where $1=$ highest freedom and $10=$ lowest or no freedom. From the continuous variable of freedom an indicator variable, free ind is constructed: if freedom is 5 or below, then free ind $=1$ and if above 5 , then it equals 0 . Executive Recruitment Quality Index (exrec) shows the best if it is 10 and worst if it is 0 . It has also been converted into an indicator variable, exrec ind which is 1 if executive recruitment quality index is 5 and above, and 0 if below 5. Taking an average of ethnic, language and religion using data from a different data source which is Alesina et al. (2003) a new variable named ELR has been created.

The ELF data are collected from Atlas Narodov Mira published in the then Soviet Union in 1964. These ethnolinguistic fractionalization variables, although covers many ethnic, religious and linguistic aspects, fail to capture the heterogeneity among data points by failing to distinguish differences between linguistic and ethnic variables as language itself is used in measuring ethnicity.

To use a quantitative measure of corruption, data are collected from World Bank Enterprise Survey and other macro variables are taken from WDI (world Bank).

\section{Description of Variables}

Growth regression equations typically include a modest subset of the body of regressors that have been proposed in the literature as a whole. The dependent variable, growth is economic growth calculated by taking the average GNI growth rate over 2000-2011. corruption $(=b)$, a measure of corruption is calculated by the average of ICRG index and CPI index of Transparency International and which is an average of 12 years from 2000 to 2011. GDP of a country i.e. size of the economy in the base year would definitely influence the economic growth in subsequent years, which should, therefore, be controlled. For this, GDP per capita (in US\$) in 2000 i.e. size of economy $(=\mathrm{G})$ is used in the regression equations as a variable. investment $(=I)$ standing for gross investment of the country is measured by the gross domestic capital formation in 2000, which is expected to control for the differentials in achieving growth in years following 2000 due to differences in capital stock already held by countries. consumption (C) i.e. general government final consumption expenditure as a \% of GDP (average of 2000-2011) is used as another control because the countries having huge population have to spend a lot for consumption, which impacts the GNI growth strongly positively.

Economic theories suggest and empirical works find that stock of human capital and the quality of human capital play important roles in augmenting economic growth (for example, Mankiw et al. (1992) used a proxy for the rate of human-capital accumulation that measures approximately the percentage of the working-age population that is in secondary school); therefore, as a measure of the stock of human capital owned by countries $(H)$ the literacy rate (literacy) and for the quality of human capital (human), pupil-teacher ratio in primary schools in 2000 are used. Higher rates of literacy indicate a larger stock of human capital which contributes to growth because educated people have low fertility rates and high ratios of physical investment to GDP (Barro 1991). Pupil-teacher ratio is a good indicator of the quality of 
human capital because the attainment of education depends on the number of pupils taught by one teacher. The smaller the ratio of the number of pupils to teacher, the better for the learning success of students who will have better technical know-how when they enter into working life. This is the reason why development agencies provide funds to poorer countries to employ more teachers. As Nelson and Phelps (1966) suggest, for a country to catch up with other countries inventing new products, ideas and technology by absorbing them requires human capital of large stock and high quality. Rapid population growth putting huge pressure on public spending is seen to have a retarding effect on growth in many developing countries such as Bangladesh and India. To control for this effect population growth (=P) i.e. the average of population growth rates of 12 years has been used in the regression equations. Aid and Development Assistance received by a country is supposed to affect its growth rate, therefore, assistance \& aid (average official development assistance \& aid received (constant 2010 US\$) over 2000-11) has been included as an independent variable.

In the Instrumental Variable (IV) regression corruption has been instrumented by ELF i.e. EthnoLinguistic Fractionalization Index which is the average of 3 indices on ethnicity, language and religion to address the possible endogeneity problems. In order to investigate if the effect of corruption on growth varies if it is interacted with countries' freedom status and executive recruitment quality, freedom index and executive recruitment quality are put in interaction with the corruption variable in the OLS regressions. These two variables are used as both continuous and indicator variables consecutively. freedom is measured by the average of political rights and civil liberties indices $(1=$ highest free; $10=$ lowest). free ind, is a dummy for a country: if it has satisfactory degree of freedom i.e. if freedom index is 5 or below, then $=1$ and if freedom index is above 5, then it equals 0 . exrec is executive recruitment quality index which, if 0 is the lowest and if $10=$ is the highest. exrec ind is a dummy for executive recruitment quality in the country. exrec_ind $=1$ if executive recruitment quality is 5 or above and $=0$ if below 5 (10=highest and $1=$ lowest $)$.

Initially a vector of regional dummies was used to cancel out the suspected regional effects on growth. A regional dummy was used for each of the following: Africa, East Asia and Pacific, Europe and Central Asia, Latin America and Caribbean, Middle East and North Africa, South Asia; but the effect each of these regions exerted, was found to be totally insignificant. That's why these regional dummies are all dropped.

In the second stage when a panel dataset has been used for the analysis, a new variable called openness has been added in the regression as Fischer (1993) finds evidence that macroeconomic policy causes growth to change. openness is measured by (import/GDP + export/GDP). To look at the multiplicative effect of corruption and openness on growth another variable called interaction has also been used, which is constructed by multiplying corruption by openness. In the estimation methods on panel data models initial GDP per capita in 2000 as an explanatory variable is no longer used because regressions in such models treat this variable as a 'fixed effect' (Swaleheen, 2011).

\section{Measurement Issues}

Measurement of corruption indices is a debatable issue inside and outside academia because these indices are constructed on the basis of perceptions of business people, experts and others having experience of paying bribe or knowledge in the system of bribery. Perceptions are always influenced by subjectivity. Corruption indices are not free from the heterogeneity specific to countries, societies and time periods either. Therefore, it cannot be guaranteed that analyses using this kind of perception indices are free from measurement biases. Yet, Corruption Perception Index (CPI) of Transparency International and the risk index constructed by ICRG are considered the most acceptable indices in measuring corruption. They are acceptable in the sense that the articles using these indices are widely cited. This kind of articles, is huge in number. Mauro (1995), Aidt et al. (2008), You and Khagram (2005) are some of them. In this study, an average of these two indices have been taken as a measure of corruption.

The Corruption Perception Index (CPI) constructed by the Transparency International is a composite index, using data compiled or published by 13 surveys of business people and assessments by country analysts from 11 independent institutions: Africa Development Bank, Asian Development Bank, 
Bertelsmann Foundation, Economist Intelligence Unit, Freedom House, Global Insights, Institute for Management Development, Political and Economic Risk Consultancy, World Economic Forum and World Bank. A variable as a measure of corruption constructed by perception data is often criticized because, as is said, it is likely to suffer from perception biases. However, combination of data sources increases its reliability, and since all the sources employ a homogeneous definition of 'extent of corruption' and the assessments are gathered from experienced respondents, the measure is close to the real one if not the real one itself (Knack and Keefer 1995).

The International Country Risk Guide (ICRG) in rating countries in respect of various risks has included 22 variables in three subcategories: political risk, financial risk, and economic risk. A separate index is constructed for each of these subcategories. The Political Risk index is based on 100 points, Financial Risk on 50 points, and Economic Risk on 50 points. The composite country risk score is a weighted average of these 3 indices while the weights are made by dividing the total points from the three indices by 2 . The composite scores, ranging from zero to 100 , are then broken into categories from Very Low Risk (80 to 100 points) to Very High Risk (zero to 49.9 points). The Political Risk Rating includes 12 weighted variables covering both political and social attributes. ICRG has produced a so-called "Type II" forecast in which its experts provide a current assessment, a one-year assessment, and a five-year assessment. The projections of future conditions are described as "best" and "worst". ICRG provides ratings for 140 countries on a monthly basis, and for 26 countries on an annual basis (Méndez and Sepúlveda 2006). Combining and averaging corruption data from two reliable sources have further diminished the possibility of the said biases leading this analysis towards to a greater degree of accuracy.

\section{Estimation Problem}

It becomes difficult to measure the impact of corruption on macroeconomic growth ceteris paribus through standard OLS regression when the error term is correlated with one or more of the explanatory variables used in the regression. If this is the case then OLS will not provide us unbiased and consistent estimates. It might occur for a number of reasons: when the explanatory variables are correlated with the error terms, when the dependent variable causes at least one of the covariates (i.e. reverse causation), when there are relevant explanatory variables which are omitted from the model, or when the covariates are subject to measurement error. To overcome this problem, we must find an instrument for the explanatory variable responsible for such correlations i.e. the variable which is endogenously determined in the regression. Then IV regression has to be run. For a variable to qualify for an instrument is required to fulfil the following conditions: It must be correlated with the endogenous explanatory variables, conditional on the other covariates; It cannot be correlated with the error term in the explanatory equation (conditional on the other covariates), that is, the instrument cannot suffer from the same problem as the original predicting variable.

In our present case the explanatory variable, corruption is likely to cause such problem of endogeneity; therefore, we need an instrument to execute IV method which would provide us with consistent and unbiased estimates preventing wrong inferences. Ethnolinguistic Fractionalization indexpopularly known as ELF is such a variable that may serve as a good instrument. ELF has been used as an instrument and IV regression has been done by many authors in the cross-country analysis on the effect of corruption on macroeconomic growth. Mauro (1995) is the pioneer in this regard. The argument for using ELF for instrumenting corruption is that corruption level of a country has been found correlated with its ELF factor while it is not correlated with the unobservables determining the corruption level. IV regressions have also been done using ethnic, language and religion using data provided by (Alesina et al. 2003). All the instruments tested with in order to overcome the endogeneity problem through IV regressions appeared to be weak. The use of a weak instrument makes the asymptotatic theory provide a poor guide to actual finite-sample distribution i.e. results obtained from IV regressions would provide a biased estimator as well as OLS (Davidson \& MacKinnon, 2004). In case of weak instrument, it is, therefore, imperative that a new instrument be found, which is sufficiently strong. But in this present case i.e. when corruption is the variable of interest, it is difficult to find an appropriate instrument for it. A different approach which is to say, an alternative asymptotatic theory is suggested which would provide a 
more reasonable approximation. One of the several alternative estimators suggested in the literature, which are asymptotatically equivelent to 2SLS but may have better finite-sample properties is LIML estimator which is the leading so far. Recently research has revealed that LIML has got some desirable finite-sample properties such as smaller bias than 2SLS or GMM particularly when instrument is weak (Cameron and Trivedi, 2009). Accordingly, in this analysis IV regression has been run with LIML option but the results again become insignificant.

To imrove over the cross-section analysis described above, a panel dataset has also been used and some different econometric tools have been applied. Analyses on panel dataset gain efficiency because they don't need to make restrictive assumptions. More clearly, panel data would make it possible to analyse changes on individual countries over different time periods (Verbeek 2008).

\section{DISCUSSION OF RESULTS}

\section{Regression Results from Cross-section Analysis}

TABLE 1

REGRESSION PUTPUT (OLS)

\begin{tabular}{|c|c|c|c|c|}
\hline Dependent variable: growth & Model 1 & Model 2 & Model 3 & Model 4 \\
\hline \multirow[t]{2}{*}{ corruption } & $-0.399 *$ & -0.256 & $-0.418^{*}$ & -0.261 \\
\hline & $(-1.74)$ & $(-1.23)$ & $(-1.90)$ & $(-1.21)$ \\
\hline \multirow[t]{2}{*}{ size of economy } & -0.000 & -0.0001 & -0.00 & -0.000 \\
\hline & $(-0.155)$ & $(-1.336)$ & $(-0.644)$ & $(-0.495)$ \\
\hline \multirow[t]{2}{*}{ investment } & $0.155^{* *}$ & $0.150 * * *$ & $0.151 * *$ & $0.151 * * *$ \\
\hline & $(3.371)$ & $(3.426)$ & $(3.39)$ & $(3.410)$ \\
\hline \multirow[t]{2}{*}{ consumption } & $-0.110 * * *$ & $-0.090 * *$ & $-0.114 * * *$ & $-0.082^{*}$ \\
\hline & $(-3.826)$ & $(-2.677)$ & $(-4.407)$ & $(-2.289)$ \\
\hline \multirow[t]{2}{*}{ population growth } & $1.185^{*}$ & $1.322 * * *$ & $1.213 *$ & $1.279 * *$ \\
\hline & $(2.081)$ & $(3.406)$ & $(2.127)$ & $(3.237)$ \\
\hline \multirow[t]{2}{*}{ literacy } & $0.052 * *$ & $0.054 * *$ & $0.0553 * *$ & $0.055 * * *$ \\
\hline & $(2.829)$ & $(3.335)$ & $(2.910)$ & $(3.637)$ \\
\hline \multirow[t]{2}{*}{ human } & 0.0008 & & 0.006 & \\
\hline & $(0.019)$ & & $(0.144)$ & \\
\hline \multirow[t]{2}{*}{ assistance \& aid } & 0.000 & & & 0.000 \\
\hline & $(0.734)$ & & & $(1.463)$ \\
\hline $\mathrm{R}^{2}$ & 0.314 & 0.31 & 0.341 & 0.292 \\
\hline $\mathrm{R}^{2} \_\mathrm{a}$ & 0.25 & 0.273 & 0.29 & 0.247 \\
\hline $\mathrm{N}^{-}$ & 94 & 121 & 98 & 117 \\
\hline
\end{tabular}

Note: values in parentheses are t-statistics. ${ }^{*} \mathrm{p}<0.05, * * \mathrm{p}<0.01, * * * \mathrm{p}<0.001$ 
Unobserved heterogeneity was suspected in this cross-country analysis, which is why OLS was run with VCE (robust) option in Stata programme which tackles this problem of heterogeneity and the results thus obtained are robust to heteroskedasticity of the error term. Among all the OLS regressions from model 1 to 4 (see Table 1) model 1 and 3 provide the most significant coefficient of corruption, the variable of interest being significant at 10\% level and according to model 3 (the most significant), a 1point rise in corruption increases growth rate by 0.418 (Higher value of the corruption index means a lower level of corruption. Therefore, the negative coefficient of it means that a rise in corruption index i.e. a fall in corruption reduces growth rate). Model 1 which included all the control variables considered relevant according to economic theories, provides a coefficient of corruption, which is significant at $10 \%$ level. The variable, size of economy measured by GDP per capita used for controlling the size of economy has turned out to be insignificant in all specifications. In model 3, besides size of economy, human i.e. pupil-teacher ratio in primary school in 2000 used as a measure of quality of human capital in the base year, has also turned insignificant. investment i.e. investment averaged over 2000-11, population (population growth rate) and literacy rate have shown a positive impact on growth, which is intuitive. consumption i.e. general government final consumption expenditure has shown a negative impact. Since consumption expenditure reduces investment which is a key factor for growth, higher consumption expenditure retards growth. In IV regressions where corruption has been instrumented by ELF, corruption coefficient is seen to be insignificant but like OLS it also shows a negative sign of the coefficient indicating a positive impact of corruption on growth. The reason for this insignificance may be the weakness of the instrument, although even strongly instrumented variables generally perform less well than OLS when there is no endogeneity. However, Bound et al. (1995), Hahn and Hausman (2002), Nagar (1959) find that even if a weak instrument provides significant coefficient, the IV estimation would still be biased like OLS. Shaw et al. (2011) rule out the results found by Mauro (1995) from his IV estimation using ELF as an instrument for the same reason. In any case as already stated, and as confirmed by tests, endogeneity between corruption and growth is unlikely. freedom status and executive recruitment quality neither as a continuous nor as a categorical variable show any significant effect on macroeconomic growth.

Coefficients of freedom and executive recruitment quality and their interaction terms with corruption have turned out to be insignificant, which means that these two variables have any significant effect on neither growth nor do they influence the way how corruption impacts growth. In a linear regression model, the marginal/partial effect equals the relevant slope coefficient. The coefficient of the corruption variable in model 3 (table 1) and the marginal effect (table 2) found from the model with respect to corruption are the same, which is -0.4181 . This equality between the two, indicates linearity in the regression. This linearity remains intact when freedom is included as a continuous variable (i.e. coefficient of corruption from the model without freedom and that from the model (table 3 ) with freedom still remain the same, which is -0.1796$)$ but when freedom as an indicator variable or executive recruitment quality both as continuous and indicator variable alone or with their interaction terms added to the model, these two quantities become different. This difference indicates a nonlinear relation. The average marginal effect of corruption while used with freedom and its interaction term with corruption is -0.2038 (table 8) which is lower by 0.21437 than the marginal effect found from regression using the same variables except these two (table 2). It means that positive effect of corruption is diminished if freedom and its interaction term with corruption are added on the right side of the equation. It further means that although freedom itself does not come up with a significant effect individually, it controls the effect of corruption on growth to some extent. Standard error of corruption appears to be a bit higher than it is in the original equation (it increases from 0.2199 to 0.2520 ). 
TABLE 2

MARGINAL EFFECT FROM MODEL 3

\begin{tabular}{|c|c|c|c|c|c|}
\hline \multicolumn{6}{|c|}{ margins, dy/dx (corruption) } \\
\hline \multicolumn{6}{|c|}{ Expression: Linear prediction, predict () } \\
\hline \multicolumn{6}{|c|}{ dy/dx w.r.t corruption } \\
\hline & $\mathrm{dy} / \mathrm{dx}$ & $\mathrm{SE}$ & $\mathrm{t}$ & $\mathrm{P}>|\mathrm{t}|$ & [95\% Conf. Interval] \\
\hline corruption & -0.41811 & 0.219909 & -1.90 & 0.06 & 0.018776 \\
\hline
\end{tabular}

TABLE 3

MARGINAL EFFECT FROM MODEL 5

margins, dy/dx (corruption freedom)

Expression: Linear prediction, predict ()

$\mathrm{dy} / \mathrm{dx}$ w.r.t corruption

\begin{tabular}{lrrrrrr}
\hline & $\mathrm{dy} / \mathrm{dx}$ & $\mathrm{SE}$ & $\mathrm{t}$ & $\mathrm{P}>|\mathrm{t}|$ & {$[95 \%$ Conf. } & Interval $]$ \\
\hline corruption & -0.17961 & 0.228747 & -0.79 & 0.434 & -0.63419 & 0.274979 \\
\hline freedom & 0.127628 & 0.101952 & 1.25 & 0.214 & -0.07498 & 0.330237 \\
\hline
\end{tabular}

The average marginal effect of corruption when used with executive recruitment quality and its interaction term with corruption is -0.1362 (table 10 ) which is lower by $(0.4181-0.1362=) 0.2819$ than the marginal effect (table 1) obtained from the regression (model-3) using the same variables except these two. It means that positive effect of corruption is diminished if executive recruitment quality and its interaction term with corruption are added on the right side of the equation. It also means that although executive recruitment quality itself does not show any significant effect on growth individually, it reduces the extent of the effect that corruption exerts on growth to some extent. Standard error of corruption is also higher in the latter than it is in the original equation (it increases from 0.2199 to 0.2716 ). 
TABLE 4

RGRESSION (OLS)

\begin{tabular}{lll}
\hline Dependent variable: growth & Model 5 & Model 6 \\
\hline corruption & -0.179 & -0.223 \\
& $(-0.785)$ & $(-0.942)$ \\
size of economy & -0.0001 & -0.0001 \\
& $(-1.362)$ & $(-1.345)$ \\
investment & $0.151^{* *}$ & $0.153^{* *}$ \\
& 3.177 & $(3.192)$ \\
consumption & $-0.103^{* * *}$ & $-0.103^{* * *}$ \\
& $(-3.880)$ & $(-3.954)$ \\
population & 1.077 & 1.050 \\
& $(1.815)$ & $(1.854)$ \\
literacy & $0.053^{* *}$ & $0.053^{* *}$ \\
& $(2.745)$ & $(2.763)$ \\
human & $(0.003)$ & $(0.005)$ \\
& $(0.076)$ & $(0.110)$ \\
freedom & 0.127 & \\
free_ind & $(1.251)$ & -0.651 \\
r2 & & $(-1.270)$ \\
r2_a & & 0.36 \\
$\mathrm{~N}$ & 0.358 & 0.302 \\
\hline
\end{tabular}

Legend: $\mathrm{b} / \mathrm{t} .{ }^{*} \mathrm{p}<0.05,{ }^{* *} \mathrm{p}<0.01,{ }^{* * *} \mathrm{p}<0.001, \mathrm{p}<0.001$

Note: consumption $=$ government final consumption expenditure; population $=$ population growth; literacy $=$ literacy rate; human = quality of human capital; free_ind $=$ indicator variable constructed from freedom $(=1$ if freedom status is 5 or greater; otherwise 0 ). 
TABLE 5

\section{RRGTRESSION (OLS)}

\begin{tabular}{lll}
\hline Dependent variable: growth & Model 7 & Model 8 \\
\hline corruption & -0.135 & -0.172 \\
& $(-0.499)$ & $(-0.605)$ \\
size of economy & 0.0001 & 0.0001 \\
& $(-1.619)$ & $(-1.641)$ \\
investment & $0.147^{* *}$ & $0.149^{* *}$ \\
& $(2.743)$ & $(-2.778)$ \\
consumption & $-0.113^{* * *}$ & $-0.112^{* * *}$ \\
& $(-4.464)$ & $(-4.654)$ \\
population & 0.857 & 0.888 \\
& $(1.284)$ & $(1.356)$ \\
literacy & $0.046^{*}$ & $0.046^{*}$ \\
& $(2.303)$ & $(2.384)$ \\
human & 0.009 & 0.005 \\
& $(0.179)$ & $(0.107)$ \\
exec & -0.032 & \\
exrec_ind & $(-0.221)$ & 0.130 \\
r2 & & $(0.196)$ \\
r2_a & & 0.336 \\
$\mathrm{~N}$ & 0.336 & 0.271 \\
\hline
\end{tabular}

Legend: $\mathrm{b} / \mathrm{t} . * \mathrm{p}<0.05, * * \mathrm{p}<0.01, * * *$

Note: consumption $=$ government final consumption expenditure; population $=$ population growth; literacy $=$ literacy rate; human = quality of human capital; exrec $=$ executive recruitment quality; exrec_ind $=$ indicator variable constructed executive recruitment quality ( $=1$ if executive recruitment quality is 5 or greater; otherwise 0 ). 
TABLE 6

REGRESSION (OLS WITH INTERACTION TERMS)

\begin{tabular}{lcc}
\hline Dependent variable: growth & Model 9 & Model 10 \\
\hline corruption & -0.045 & -0.319 \\
freedom & $(-0.190)$ & \\
& 0.220 & \\
corruption\#freedom & $(1.120)$ & \\
size of economy & -0.030 & -0.001 \\
investment & $(-0.560)$ & $(-1.330)$ \\
consumption & 0.000 & 0.150 \\
& $(-1.380)$ & $(3.210)$ \\
population & $0.150^{* * *}$ & -0.100 \\
literacy & $(3.250)$ & $(-3.930)$ \\
human & $-0.104^{* * *}$ & 1.060 \\
& $(-3.840)$ & $(1.870)$ \\
free_ind & $1.09 *$ & $0.05)$ \\
0 & 1.81 & $(2.710)$ \\
1 & $0.050^{* * *}$ & 0.003 \\
free_ind\#c.corrpt & $(2.730)$ & $(0.070)$ \\
0 & 0.001 & \\
1 & $(0.020)$ & $0(\mathrm{base})$ \\
F & & -1.140 \\
r2 & & $(-1.050)$ \\
\hline
\end{tabular}

Legend: $\mathrm{b} / \mathrm{t} .{ }^{*} \mathrm{p}<0.05,{ }^{* *} \mathrm{p}<0.01,{ }^{* * *} \mathrm{p}<0.001, \mathrm{p}<0.001$ 
TABLE 7

REGRESSION (OLS WITH INTERACTION TERMS)

\begin{tabular}{|c|c|c|}
\hline Dependent variable: growth & Model 11 & Model 12 \\
\hline corruption & $\begin{array}{l}-0.026 \\
(-0.050)\end{array}$ & $\begin{array}{l}-0.041 \\
(-0.110)\end{array}$ \\
\hline exrec & $\begin{array}{l}0.023 \\
(0.090)\end{array}$ & \\
\hline corruption\# exrec & $\begin{array}{l}-0.018 \\
(-0.280)\end{array}$ & \\
\hline size of economy & $\begin{array}{l}-0.0001 \\
(-1.590)\end{array}$ & $\begin{array}{l}-0.0001 \\
(-1.640)\end{array}$ \\
\hline investment & $\begin{array}{l}0.146^{* * *} \\
(2.670)\end{array}$ & $\begin{array}{l}0.145^{* * * *} \\
(2.710)\end{array}$ \\
\hline consumption & $\begin{array}{l}-0.114^{* * *} \\
(-4.410)\end{array}$ & $\begin{array}{l}-0.110^{* * *} \\
(-4.610)\end{array}$ \\
\hline population & $\begin{array}{l}0.863 \\
(1.280)\end{array}$ & $\begin{array}{l}0.902 \\
(1.360)\end{array}$ \\
\hline literacy & $0.048^{* * *}$ & $0.047^{* * *}$ \\
\hline human & $\begin{array}{l}(2.330) \\
0.009\end{array}$ & $\begin{array}{l}(2.380) \\
0.005\end{array}$ \\
\hline exrec_ind & $(0.190)$ & $(0.110)$ \\
\hline 0 & & 0 (base) \\
\hline 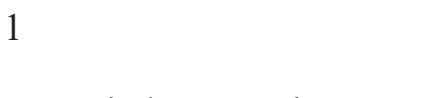 & & $\begin{array}{l}0.596 \\
(0.460)\end{array}$ \\
\hline $\begin{array}{l}\text { exrec_ind } \# \text { c.corrption } \\
0 \\
1\end{array}$ & & $\begin{array}{l}0 \text { (base) } \\
-0.171 \\
(-0.480)\end{array}$ \\
\hline $\begin{array}{l}\mathrm{F} \\
\mathrm{r} 2\end{array}$ & $\begin{array}{l}8.496 \\
0.336\end{array}$ & $\begin{array}{l}7.738 \\
0.337\end{array}$ \\
\hline
\end{tabular}

TABLE 8

MARGINAL EFFECT

With respect to corruption and freedom

\begin{tabular}{lrrr}
\hline & $\mathrm{dy} / \mathrm{dx}$ & $\mathrm{SE}$ & $\mathrm{t}$ \\
\hline corruption & -0.20388 & 0.252024 & -0.81 \\
freedom & 0.120994 & 0.103819 & 1.17 \\
\hline
\end{tabular}


TABLE 9

MARGINAL EFFECT

With respect to corruption and free ind

\begin{tabular}{lccr}
\hline \multicolumn{4}{c}{ With respect to corruption and free_ind } \\
\hline dy/dx & SE & $\mathrm{t}$ \\
\hline freedom & -0.2369 & 0.25305 & -0.94 \\
1.free_ind & -0.6137 & 0.52593 & -1.17 \\
\hline
\end{tabular}

TABLE 10

MARGINAL EFFECT

With respect to corruption and exrec

\begin{tabular}{llll}
\hline & \multicolumn{4}{c}{ Wy/dx } & SE & $\mathrm{t}$ \\
\hline corruption & -0.1362 & 0.2716 & -0.5 \\
exrec & -0.03652 & 0.144661 & -0.25 \\
\hline
\end{tabular}

TABLE 11

MARGINAL EFFECT

With respect to corruption and exrec ind

\begin{tabular}{llll}
\hline & $\mathrm{dy} / \mathrm{dx}$ & $\mathrm{SE}$ & $\mathrm{t}$ \\
\hline corruption & -0.169 & 0.2838 & -0.59 \\
1.exrec_ind & 0.0361 & 0.6479 & 0.06 \\
\hline
\end{tabular}


TABLE 12

IV REGRESSION WITH INSTRUMENT 'ELF'

\begin{tabular}{lrrr}
\hline Dependent variable: growth & Model 13 & Model 14 & Model 15 \\
\hline corruption & -28.281 & -28.281 & -28.281 \\
& $(-0.117)$ & $(-0.115)$ & $(-0.121)$ \\
size of economy & 0.002 & 0.002 & 0.002 \\
& $(0.114)$ & $(0.113)$ & $(0.117)$ \\
investment & 0.080 & 0.080 & 0.080 \\
& $(0.103)$ & $(0.098)$ & $(0.102)$ \\
consumption & -0.437 & -0.437 & -0.437 \\
& $(-0.161)$ & $(-0.154)$ & $(-0.161)$ \\
population & -4.793 & -4.793 & -4.793 \\
& $(-0.094)$ & $(-0.091)$ & $(-0.095)$ \\
literacy & -0.245 & -0.245 & -0.245 \\
& $(-0.093)$ & $(-0.093)$ & $(-0.097)$ \\
human & -0.500 & -0.500 & -0.500 \\
& $(-0.110)$ & $(-0.111)$ & $(-0.116)$ \\
$\mathrm{R}^{2}$ & $\cdot$ & 97.451 & 97.451 \\
$\mathrm{R}^{2}$ a & 9 & -105.194 & -105.194 \\
$\mathrm{~N}$ & $9.01, * * * p<0.001$ & 97 & 97 \\
\hline
\end{tabular}

Overall significance of the regressions or in other words, the joint significance of the regressors read by prob $>\mathrm{F}$ values $(0.000)$ in F test is high in standard OLS regressions - mainly in model 3 which provides the best corruption coefficient. $\mathrm{R}^{2}$ values range 0.33 to 0.57 and adjusted $\mathrm{R}^{2}$ are from 0.247 to 0.52 in standard OLS. It means that the explanatory variables used in the models above explain from $30 \%$ to $55 \%$ of the changes in macroeconomic growth, which is satisfactory in respect of the model fit. $\mathrm{R}^{2}$ and adjusted $\mathrm{R}^{2}$ values in the IV regression are not satisfactory, which indicates that the use of instrumental variable in the IV regressions reduces the explanatory power of the model.

Between OLS and IV, which estimator should be used for inferences is an important decision. In the present case OLS estimates are more appropriate than the IV for the following reasons: Regressors used in the OLS are found to be exogenous in all reliable statistical tests at $10 \%$ level of significance. Secondly, standard errors in the IV regressions are much larger than those in standard OLS regressions. "A larger variance means a less precise estimator, and this translates into larger confidence intervals and less accurate hypotheses tests" (Wooldridge, 2009, p.95). IV estimates do tend, as a general rule, to have higher standard errors than OLS ones and this by itself is not a reason to prefer OLS. But when there is no reason to suspect endogeneity, then it is a valid reason to choose OLS. The variance found in IV is larger than the variance in OLS, which also indicates more noise in the regression equation making it more difficult to estimate the partial effect of corruption on growth (Wooldridge 2009). The presence of heteroskedasticity does not cause OLS to be biased although OLS does not any longer have the smallest variance among linear unbiased estimators in the presence of heteroskedasticity (Wooldridge 2009). Moreover, this heteroskedasticity problem is solved by VCE option with OLS in Stata. 
Therefore, making inferences on the basis of OLS estimator is more appropriate. Accordingly, a 1-point rise in corruption increases growth rate by 0.418 on average. In brief, the impact of corruption level of a country on its growth is positive but small.

\section{Tests}

Reading the t-statistic or p-value for each variable in the OLS regressions, the relevance or the redundancy of it can be determined. 7 control variables have been used in the regression equations (see Table 4). Among those, GDP per head in 2000 (size of economy), quality of human capital (human capital) and development assistance and aid (assistance \& aid) do not show significance in any of the OLS regressions implying no significant effect on macroeconomic growth. However, the first two of these three variables i.e. size of economy and human capital play significant roles in making corruption, the main variable of interest significant. Therefore, assistance \& aid may be declared redundant in the model but not size of economy and human capital. freedom and executive recruitment quality are seen to be insignificant as both continuous and indicator variables. In the regressions done with a view to finding the marginal effects of corruption with and without satisfactory levels (average) of freedom and executive recruitment quality they turn out to be insignificant also. Yet, they are not declared redundant because the mentioned marginal effect found, contains some information about the differences in the effect of corruption while interacted with freedom and executive recruitment quality separately.

To test multicollinearity between explanatory variables VIF (variance inflation factor) test has been conducted and VIF values for each variable found from all regressions have been far below 10 (an acceptable threshold) declare the absence of multicollinearity between explanatory variables used the regression analysis.

To check if any relevant variable in the equation regressing growth has been omitted, the Ramsey RESET test has been conducted. In all these tests done subsequently after each regression p-value of greater than 0.05 does not reject the null that the model has no omitted variables. It means that the variables included in the models can sufficiently explain the changes in macroeconomic growth.

The Breusch-Pagan / Cook-Weisberg test is used to check the presence of heterogeneity. P-values of greater than 0.1 in the models from 1 to 4 do not reject the null of constant variance at any conventional level and in models 5 and 6, p-values of .08 and .06 respectively do not reject the null at 5\% level. It declares non-existence of heterogeneity mainly in model 3 on the basis of which inference has been made.

TABLE 13

\begin{tabular}{l} 
Tests of endogeneity of: corruption \\
\hline Ho: variables are exogenous \\
Robust score chi2 $(1)=.810818(\mathrm{p}=0.3679)$ \\
$\begin{array}{l}\text { Robust regression } \mathrm{F}(1,107)=.757049 \\
(\mathrm{p}=0.3862)\end{array}$
\end{tabular}




\section{TABLE 14}

Tests of endogeneity of: corruption

H0: Regressor is exogenous

Wu-Hausman F test: $1.97075 \mathrm{~F}(1,88)$

P-value $=0.16389$

Durbin-Wu-Hausman chi-sq test:

2.12472

Chi-sq(1) P-value $=0.14494$

\section{Regression Results from Panel Data}

$O L S$

Table 15 presents the regression output obtained from OLS estimator. As has already been discussed, estimates have been done on panel dataset in order to overcome the problems that could not be tackled in cross-section data and also to check the robustness of the results found in the cross-section analysis. In model 1, 3 and 4 the coefficient of the variable of interest i.e. corruption has appeared to be significant in $1 \%$ level. Since corruption is, in fact, a measure of governance quality, negative sign of the corruption coefficients indicates a positive impact of corruption. It is seen that a 1-point rise in corruption leads to a rise in growth rate by $0.639,0.604$ and 0.721 in model 1, 3 and 4 respectively (table 15). Model 6 (table 15) shows the corruption coefficient to be significant at $10 \%$ level and in this specification as well, corruption is seen to have a positive impact of similar magnitude on growth.

The policy variable, openness which is measured by a country's export and import as a share of GDP, is seen to have a positive but small effect on growth (significant at $10 \%$ level) only in model 1 (table 15). It indicates that involvement in international trade helps countries grow faster. openness becomes insignificant when corruption squared, openness squared or interaction are added in the regression (see model 2, 3 and 5 in table 15).

The interaction variable constructed multiplying openness by corruption, appears to be significant with a positive sign in model 4 (table 15). It means that the positive impact of corruption on growth is slightly diminished when it is interacted with openness (the coefficient of corruption is -0.721 and coefficient of the interaction term is +0.002 ; therefore, the effect of corruption in combination with openness is to be measured by $-0.719(-0.721+0.002=))$. consumption, literacy, population, human turned out to be insignificant in all specifications. investment, quite intuitively, is seen to impact growth positively at a highly significant level. 
TABLE 15

OLS ON PANEL DATA

\begin{tabular}{|c|c|c|c|c|c|c|}
\hline Dependent variable: growth & $\begin{array}{r}\text { Model } 1 \\
\text { OLS }\end{array}$ & $\begin{array}{r}\text { Model } 2 \\
\text { OLS }\end{array}$ & $\begin{array}{r}\text { Model } 3 \\
\text { OLS }\end{array}$ & $\begin{array}{r}\text { Model } 4 \\
\text { OLS }\end{array}$ & $\begin{array}{r}\text { Model } 5 \\
\text { OLS }\end{array}$ & $\begin{array}{r}\text { Model } 6 \\
\text { OLS }\end{array}$ \\
\hline corruption & $\begin{array}{c}-0.639 * * \\
(-2.634)\end{array}$ & $\begin{array}{r}-1.5 \\
(-1.554)\end{array}$ & $\begin{array}{c}-0.604 * * \\
(-2.628)\end{array}$ & $\begin{array}{r}-0.721 * * \\
(-2.889)\end{array}$ & $\begin{array}{r}-0.76 \\
(-1.918)\end{array}$ & $\begin{array}{l}-0.643 * \\
(-2.437)\end{array}$ \\
\hline openness & $\begin{array}{c}0.010 * \\
(2.32)\end{array}$ & $\begin{array}{r}0.008 \\
(1.846)\end{array}$ & $\begin{array}{r}-0.005 \\
(-0.514)\end{array}$ & & $\begin{array}{r}-0.002 \\
(-0.127)\end{array}$ & \\
\hline investment & $\begin{array}{r}0.189 * * * \\
(5.404)\end{array}$ & $\begin{array}{r}0.186 * * * \\
(5.382)\end{array}$ & $\begin{array}{r}0.187 * * * \\
(5.441)\end{array}$ & $\begin{array}{r}0.185 * * * \\
(5.363)\end{array}$ & $\begin{array}{r}0.185 * * * \\
(5.357)\end{array}$ & $\begin{array}{r}0.188 * * * \\
(5.427)\end{array}$ \\
\hline consumption & $\begin{array}{r}-0.048 \\
(-1.187)\end{array}$ & $\begin{array}{r}-0.067 \\
(-1.678)\end{array}$ & $\begin{array}{r}-0.055 \\
(-1.358)\end{array}$ & $\begin{array}{r}-0.064 \\
(-1.615)\end{array}$ & $\begin{array}{r}-0.063 \\
(-1.573)\end{array}$ & $\begin{array}{r}-0.055 \\
(-1.356)\end{array}$ \\
\hline literacy & $\begin{array}{r}-0.009 \\
(-0.770)\end{array}$ & $\begin{array}{r}-0.014 \\
(-1.313)\end{array}$ & $\begin{array}{r}-0.012 \\
(-1.117)\end{array}$ & $\begin{array}{c}-0.014 \\
(-1.274)\end{array}$ & $\begin{array}{c}-0.013 \\
(-1.219)\end{array}$ & $\begin{array}{r}-0.012 \\
(-1.097)\end{array}$ \\
\hline population & $\begin{array}{l}0.115 \\
(0.69)\end{array}$ & $\begin{array}{l}0.203 \\
(1.24)\end{array}$ & $\begin{array}{r}0.207 \\
(1.271)\end{array}$ & $\begin{array}{r}0.206 \\
(1.262)\end{array}$ & $\begin{array}{r}0.207 \\
(1.265)\end{array}$ & $\begin{array}{r}0.212 \\
(1.296)\end{array}$ \\
\hline human & $\begin{array}{r}0.236 \\
(1.174)\end{array}$ & $\begin{array}{r}0.286 \\
(1.504)\end{array}$ & $\begin{array}{r}0.302 \\
(1.605)\end{array}$ & $\begin{array}{r}0.281 \\
(1.493)\end{array}$ & $\begin{array}{r}0.282 \\
(1.495)\end{array}$ & $\begin{array}{r}0.298 \\
(1.578)\end{array}$ \\
\hline corruption squared & & $\begin{array}{r}0.176 \\
(1.051)\end{array}$ & & & & \\
\hline openness squared & & & $\begin{array}{r}0.000 \\
(1.426)\end{array}$ & & & \\
\hline interaction & & & & $\begin{array}{l}0.002 * \\
(2.114)\end{array}$ & $\begin{array}{r}0.003 \\
(0.750)\end{array}$ & $\begin{array}{r}-0.000 \\
(-0.062)\end{array}$ \\
\hline interaction squared & & & & & & $\begin{array}{r}0.000 \\
(0.929)\end{array}$ \\
\hline $\begin{array}{l}\text { R-squared } \\
\text { r2 } \\
\text { r2_a }\end{array}$ & & & & & & \\
\hline $\mathrm{N}$ & 373 & 373 & 373 & 373 & & 373 \\
\hline
\end{tabular}

$* \mathrm{p}<0.05, * * \mathrm{p}<0.01, * * * \mathrm{p}<0.001$; figures in parentheses are t-values. Consume is government consumption. 


\section{Fixed Effects}

Table 16 presents the results obtained from the models using fixed effects estimator which controls for unobserved time invariant country specific factors that cross-sectional models ignored. In the Fixed Effects estimator corruption coefficient has appeared with the same sign as in OLS but the magnitude of the impact of corruption has increased when the variable, corruption-squared is added (model 8, 9 and 10 in table 16). These coefficients are respectively $-3.258,-3.258$ and -3.567 . It means that corruption has a nonlinear effect on growth, which further means that the positive impact of corruption on growth is larger at higher levels of corruption. It supports the findings and theories that corruption, in particular, bribe helps to speed up the economic activities when the economy is stuck in high level of corruption. In FE estimator government consumption has appeared to be significant saying that higher government consumption expenditure requires more taxation and more taxation reduces growth.

\section{GMM Estimator}

In table 17, model 11 to 14 are showing results from the system GMM estimator. Among these, none of the models have a significant coefficient of the variable of our interest i.e. corruption. In this regression the control variables that are significant are lagged dependent variable (lagged growth), investment and the interaction term only. Blundell and Bond (1998) refer to situations where the lagged dependent and explanatory variables are persistent. The same is seen to be the case here. The interaction term named 'interaction' consisting of 'corruption' and 'openness of countries' appears to be positive in model 14 meaning that the positive impact of corruption on growth is slightly diminished when it is interacted with openness. However, the role of openness in the impact of corruption on growth is found to be small.

In table 18, model 15 shows the estimation from first difference one-step GMM estimator and model 16 shows first difference two-step GMM estimator. The first difference one-step GMM estimator provides a significant coefficient of corruption and also a significant positive coefficient of the interaction term. As before, summing up these two coefficients we find that a 1-point rise in the level of corruption increases growth rate by $3.747(-3.817+0.070=)$. Model 17 and 18 provide estimates from forward orthogonal deviation GMM estimator. In these models, corruption does not appear to be significant. The estimates provided by the GMM estimators above would not be valid if they suffered from autocorrelation and overidentification. Model 10,11, 12 and 13 pass the test of serial correlation of order 1. Model 10, 11, 12 and 13 pass the Sargan Overidentification test at 10\% level. Model 14 passes the test of serial correlation of order 1, Model 15 passes the test of serial correlation of order 2, Model 16 passes the test of serial correlation of order 2, Model 17 passes the test of serial correlation of order 1, Model 18 passes the test of serial correlation of order 1. Model 15 and 16 pass the Sargan of Overidentification test at $10 \%$ level. 


\section{TABLE 16}

FIXED EFFECT

\begin{tabular}{|c|c|c|c|c|}
\hline Dependent variable: growth & $\begin{array}{r}\text { Model } 7 \\
\text { FE }\end{array}$ & $\begin{array}{r}\text { Model } 8 \\
\text { FE }\end{array}$ & $\begin{array}{r}\text { Model } 9 \\
\text { FE }\end{array}$ & $\begin{array}{r}\text { Model } 10 \\
\text { FE }\end{array}$ \\
\hline corruption & $\begin{array}{r}-0.476 \\
(-1.119)\end{array}$ & $\begin{array}{l}-3.258 * \\
(-2.276)\end{array}$ & $\begin{array}{l}-3.258 * \\
(-2.278)\end{array}$ & $\begin{array}{l}-3.567 * \\
(-2.308)\end{array}$ \\
\hline openness & $\begin{array}{r}0.047 \\
(1.732)\end{array}$ & $\begin{array}{r}0.049 \\
(1.927)\end{array}$ & $\begin{array}{r}0.057 \\
(1.442)\end{array}$ & \\
\hline investment & $\begin{array}{r}0.199 * * \\
(2.741)\end{array}$ & $\begin{array}{r}0.192 * * \\
(2.665)\end{array}$ & $\begin{array}{l}0.188 * \\
(2.473)\end{array}$ & $\begin{array}{r}0.224 * * \\
(3.066)\end{array}$ \\
\hline consumption & $\begin{array}{l}-0.278^{*} \\
(-2.339)\end{array}$ & $\begin{array}{l}-0.270 * \\
(-2.338)\end{array}$ & $\begin{array}{l}-0.271 * \\
(-2.323)\end{array}$ & $\begin{array}{l}-0.280 * \\
(-2.403)\end{array}$ \\
\hline literacy & $\begin{array}{r}-0.098 \\
(-1.783)\end{array}$ & $\begin{array}{r}-0.085 \\
(-1.539)\end{array}$ & $\begin{array}{r}-0.087 \\
(-1.566)\end{array}$ & $\begin{array}{r}-0.08 \\
(-1.446)\end{array}$ \\
\hline population & $\begin{array}{r}0.65 \\
(1.142)\end{array}$ & $\begin{array}{r}0.597 \\
(1.024)\end{array}$ & $\begin{array}{r}0.593 \\
(1.000)\end{array}$ & $\begin{array}{r}0.407 \\
(0.716)\end{array}$ \\
\hline human & $\begin{array}{r}-0.021 \\
(-0.028)\end{array}$ & $\begin{array}{r}-0.056 \\
(-0.077)\end{array}$ & $\begin{array}{r}-0.06 \\
(-0.081)\end{array}$ & $\begin{array}{r}0.016 \\
-0.023\end{array}$ \\
\hline corruption squared & & $\begin{array}{c}0.498 * \\
(2.035)\end{array}$ & $\begin{array}{c}0.500 * \\
(2.030)\end{array}$ & $\begin{array}{r}0.455 \\
(1.829)\end{array}$ \\
\hline openness squared & & & $\begin{array}{r}0 \\
(-0.239)\end{array}$ & \\
\hline interaction & & & & $\begin{array}{r}0.006 \\
(0.949)\end{array}$ \\
\hline R-squared & 2.995 & 3.251 & 3.039 & 2.992 \\
\hline r2 & 0.165 & 0.18 & 0.18 & 0.16 \\
\hline r2_a & 0.147 & 0.159 & 0.157 & 0.139 \\
\hline $\mathrm{N}$ & 373 & 373 & 373 & 373 \\
\hline
\end{tabular}

$* \mathrm{p}<0.05,{ }^{* *} \mathrm{p}<0.01, * * * \mathrm{p}<0.001 ;$ figures in parentheses are t-values. 
TABLE 17

(A) GMM

\begin{tabular}{|c|c|c|c|c|}
\hline Dependent variable: growth & $\begin{array}{r}\text { Model } 11 \\
\text { system } \\
\text { GMM }\end{array}$ & $\begin{array}{r}\text { Model } 12 \\
\text { system } \\
\text { GMM }\end{array}$ & $\begin{array}{r}\text { Model } 13 \\
\text { system } \\
\text { GMM }\end{array}$ & $\begin{array}{r}\text { Model } 14 \\
\text { system } \\
\text { GMM }\end{array}$ \\
\hline lagged growth & $\begin{array}{c}0.245^{* *} \\
(3.072)\end{array}$ & $\begin{array}{c}0.244 * * \\
(3.055)\end{array}$ & $\begin{array}{c}0.244 * * \\
(3.051)\end{array}$ & $\begin{array}{c}0.243 * * \\
(3.023)\end{array}$ \\
\hline corruption & $\begin{array}{r}-0.258 \\
(-1.052)\end{array}$ & $\begin{array}{r}-1.222 \\
(-1.484)\end{array}$ & $\begin{array}{r}-0.3 \\
(-1.255)\end{array}$ & $\begin{array}{r}-0.471 \\
(-1.734)\end{array}$ \\
\hline investment & $\begin{array}{r}0.149 * * * \\
(3.879)\end{array}$ & $\begin{array}{r}0.148 * * * \\
(3.838)\end{array}$ & $\begin{array}{r}0.137 * * * \\
(3.491)\end{array}$ & $\begin{array}{r}0.137 * * * \\
(3.528)\end{array}$ \\
\hline consumption & $\begin{array}{r}-0.046 \\
(-1.192)\end{array}$ & $\begin{array}{r}-0.044 \\
(-1.136)\end{array}$ & $\begin{array}{r}-0.046 \\
(-1.195)\end{array}$ & $\begin{array}{r}-0.042 \\
(-1.104)\end{array}$ \\
\hline literacy & $\begin{array}{r}-0.014 \\
(-1.166)\end{array}$ & $\begin{array}{r}-0.014 \\
(-1.186)\end{array}$ & $\begin{array}{r}-0.019 \\
(-1.518)\end{array}$ & $\begin{array}{r}-0.018 \\
(-1.478)\end{array}$ \\
\hline population & $\begin{array}{r}0.185 \\
(1.237)\end{array}$ & $\begin{array}{r}0.181 \\
(1.203)\end{array}$ & $\begin{array}{r}0.145 \\
(0.975)\end{array}$ & $\begin{array}{r}0.147 \\
(1.002)\end{array}$ \\
\hline human & $\begin{array}{r}0.261 \\
(1.196)\end{array}$ & $\begin{array}{r}0.261 \\
(1.154)\end{array}$ & $\begin{array}{r}0.212 \\
(0.990)\end{array}$ & $\begin{array}{r}0.212 \\
(1.009)\end{array}$ \\
\hline corruption-squared & & $\begin{array}{r}0.171 \\
(1.204)\end{array}$ & & \\
\hline openness & & & $\begin{array}{l}0.007 * \\
(2.161)\end{array}$ & \\
\hline interaction & & & & $\begin{array}{c}0.002 * * \\
(2.701)\end{array}$ \\
\hline $\begin{array}{l}\text { R-squared } \\
\text { r2 } \\
\text { r2_a }\end{array}$ & 7.782 & 6.977 & 7.719 & 9.176 \\
\hline $\mathrm{N}$ & 370 & 370 & 370 & 370 \\
\hline
\end{tabular}

${ }^{*} \mathrm{p}<0.05,{ }^{* *} \mathrm{p}<0.01,{ }^{* * *} \mathrm{p}<0.001 ;$ figures in parentheses are $\mathrm{t}$-values 
TABLE 18

(B) GMM

\begin{tabular}{|c|c|c|c|c|}
\hline Dependent variable: growth & $\begin{array}{r}\text { Model } 15 \\
\text { first difference } \\
\text { One-step } \\
\text { GMM }\end{array}$ & $\begin{array}{r}\text { Model } 16 \\
\text { first difference } \\
\text { Two-step } \\
\text { GMM }\end{array}$ & $\begin{array}{r}\text { Model } 17 \\
\text { orthogonal } \\
\text { GMM }\end{array}$ & $\begin{array}{r}\text { Model } 18 \\
\text { orthogonal } \\
\text { GMM }\end{array}$ \\
\hline lagged growth & $\begin{array}{r}-0.216 \\
(-1.628)\end{array}$ & $\begin{array}{r}-0.24 \\
(-1.737)\end{array}$ & $\begin{array}{c}0.254 * * \\
(2.971)\end{array}$ & $\begin{array}{r}0.241 * * \\
(2.895)\end{array}$ \\
\hline corruption & $\begin{array}{r}-3.817 * * \\
(-3.244)\end{array}$ & $\begin{array}{r}-5.679 \\
(-0.958)\end{array}$ & $\begin{array}{r}-0.789 \\
(-0.722)\end{array}$ & $\begin{array}{r}-0.658 \\
(-1.967)\end{array}$ \\
\hline interaction & $\begin{array}{r}0.070 * * * \\
(3.465)\end{array}$ & $\begin{array}{l}0.078 * \\
(2.329)\end{array}$ & $\begin{array}{l}0.002 * \\
(2.496)\end{array}$ & $\begin{array}{r}0.003 * * \\
(3.216)\end{array}$ \\
\hline investment & $\begin{array}{r}0.175 \\
-0.701\end{array}$ & $\begin{array}{c}0.29 \\
-0.776\end{array}$ & $\begin{array}{r}0.141 * * * \\
-3.593\end{array}$ & $\begin{array}{r}0.149 * * * \\
-3.741\end{array}$ \\
\hline consumption & $\begin{array}{r}-0.154 \\
(-0.352)\end{array}$ & $\begin{array}{r}0.222 \\
-0.199\end{array}$ & $\begin{array}{r}-0.019 \\
(-0.470)\end{array}$ & $\begin{array}{r}-0.015 \\
(-0.307)\end{array}$ \\
\hline literacy & $\begin{array}{r}-0.126 \\
(-0.593)\end{array}$ & $\begin{array}{r}-0.362 \\
(-0.620)\end{array}$ & $\begin{array}{r}-0.027 \\
(-1.532)\end{array}$ & $\begin{array}{r}-0.021 \\
(-1.049)\end{array}$ \\
\hline population & $\begin{array}{r}-2.974 \\
(-0.620)\end{array}$ & $\begin{array}{r}-4.071 \\
(-0.708)\end{array}$ & $\begin{array}{r}0.081 \\
-0.416\end{array}$ & $\begin{array}{r}-0.001 \\
(-0.003)\end{array}$ \\
\hline human & $\begin{array}{r}5.03 \\
-1.14\end{array}$ & $\begin{array}{r}2.459 \\
-0.299\end{array}$ & $\begin{array}{r}0.161 \\
-0.722 \\
0.064\end{array}$ & $\begin{array}{r}0.244 \\
-1.022\end{array}$ \\
\hline corruption-squared & 2.91 & 3.862 & $\begin{array}{r}-0.326 \\
6.771\end{array}$ & 7.775 \\
\hline $\begin{array}{l}\text { R-squared } \\
\text { r2 } \\
\text { r2_a }\end{array}$ & & & & \\
\hline $\mathrm{N}$ & 370 & 370 & 370 & 370 \\
\hline
\end{tabular}

${ }^{*} \mathrm{p}<0.05,{ }^{* *} \mathrm{p}<0.01, * * * \mathrm{p}<0.001$; figures in parentheses are t-values

Robust score chi2 Test, Robust regression F Test, Wu-Hausman F test, Durbin-WuHausman chisq test are all conducted to check the presence of endogeneity in the OLS regressions. Hausman test couldnot be done as the model fitted on these data fails to meet the asymptotatic assumptions of the Hausman test. Each of the tests mentioned above fails to reject the null that the variable is exogenous at any conventional level. It may, therefore, be concluded that the main variable of interest, corruption is exogenous in the regressions and thus the regressions do not suffer from the problem of endogeneity. 
Ivreg2 command in Stata for running IV regression automatically provides tests for under-identification test (Anderson canon corr. LM statistic) and over-identification test (Sargan statistic), which reveal that IV equation is exactly identified.

\section{CONCLUDING REMARKS}

Currently available indicators of corruption are too generalized. They do not distinguish between high level of corruption and low level of corruption and between well-organized and poorly organized corruption. The indicators, if not categorized and impact is not studied separately, would show misleading effects because, for example, poorly organized corruption might have harmful effects while wellorganized corruption might have positive effects (for details see Shleifer and Vishny, 1993). Based on a simple cross tabulation of growth and corruption data, Wedeman (1997) finds many countries with high level of corruption and high rates of growth simultaneously and explains that not the overall level of corruption is significant for the GDP growth rate of a country rather certain forms of corruption have influence on the economic growth. Earlier studies show mixed results about the relationship between corruption and GDP growth.

In this study, the coefficients of corruption in both OLS and IV techniques applied on cross-section data are insignificant and those from panel data are significant. However, in both cases the sign of the coefficient is positive. That is, the use of perception-based corruption indices provided positive coefficient of corruption. Influence of recruitment quality and freedom on corruption and then on economic growth, suggest that we improve recruitment quality and freedom status of countries.

A key forward step would be to look at corruption as a component of the overall governance problem. Is slow growth due to corruption or due to pure inefficiency? Corruption studies, beginning with Mauro (1995), tend to put these two together. However, decoupling these two would be useful. Legal and enforcement measures and development of institutions have to be undertaken simultaneously. Only punishment of corrupt government officials would not work if institutions are not built. Development of institutions would bring efficient and honest bureaucracy in future but the existing bureaucracy needs to be reformed as well. The opportunities (such as discretionary power) for corrupt practices have to be reduced by simplifying the regulatory procedures firms have to go through. This will not only bring benefits by reducing corruption, it will also reduce the administrative burden.

To examine the impact of corruption on macro variables country-specific case study type research rather than cross-country analysis has to be conducted. It may, therefore, be suggested that remedies for corruption should also be country-specific i.e. type of remedial measures should depend on the type of corruption existing in the country (Shaw et al 2011).

\section{ACKNOWLEDGEMENT}

Dr. Ajit Mishra, Professor John Hudson, Mr. Ahmed Us Samad Chowdhury 


\section{REFERENCES}

Acemoglu, D., \& Johnson, S. (2005). Unbundling institutions. Journal of Political Economy, 113(5), 949-95.

Acemoglu, D., \& Robinson, J. A. (2012). Why nations fail. London: Profile Books.

Acemoglu, D., Johnson, S., Robinson, J. A., \& Yared, P. (2008). Income and democracy. American Economic Review, 98(3), 808-842.

Acemoglu, D., \& Verdier, T. (1998). Property rights, corruption and the allocation of talent: a general equilibrium approach. The Economic Journal, 108(450), 1381-1403. Retrieved from http://www.jstor.org/stable/pdfplus/2566185.pdf?acceptTC=true

Aidt, T., Dutta, J., \& Sena, V. (2008). Governance regimes, corruption and growth: Theory and evidence. Journal of Comparative Economics, 36(2), 195-220. Retrieved from http://ac.elscdn.com/S0147596707000868/1-s2.0-S0147596707000868-main.pdf?_tid=3736ea9a-5678-11e28aaf-00000aab0f6c\&acdnat=1357308689 5e58ba20920bb34f79453fec4ce65a3a

Alesina, A., Devleeschauwer, A., Easterly, W., Kurlat, S., \& Wacziarg, R. (2003). Fractionalization. Journal of Economic Growth, 8(2), 155-194. Retrieved from http://www.jstor.org/stable/pdfplus/40215942.pdf?acceptTC=true

Alesina, A., \& Weder, B. (1999). Do corrupt governments receive less foreign aid? National bureau of economic research.

Anderson, T. W., \& Hsiao, C. (1982). Formulation and estimation of dynamic models using panel data. Journal of Econometrics, 18(1), 47-82.

Arellano, M., \& Bond, S. (1991). Some tests of specification for panel data: Monte Carlo evidence and an application to employment equations. The Review of Economic Studies, 58(2), 277-297.

Arellano, M., \& Bover, O. (1995). Another look at the instrumental variable estimation of.

Arellano, M., \& Honore, B. (1999). Panel data models: Some recent evidence. Working Paper, Princeton University. Retrieved from http://www. princeton. edu/ honore/papers.

Barro, R. J. (1991). Economic growth in a cross-section of countries. Quarterly Journal of Economics, 106(2), 407-443. https://doi.org/10.2307/2937943

Baum, C. F., \& Christopher, F. (2006). An introduction to modern econometrics using Stata. Stata press.

Bayley, D. H. (1966). The effects of corruption in a developing nation. The Western Political Quarterly, 719-732.

Becker, G. S., Murphy, K. M., \& Tamura, R. (1994). Human capital, fertility, and economic growth. In Human Capital: A Theoretical and Empirical Analysis with Special Reference to Education (3rd Edition) (pp. 323-350). The University of Chicago Press.

Ben Ali, M. S., \& Saha, S. (2016). Corruption and economic development. In M. S. Ben Ali (Ed.), Economic Development in the Middle East and North Africa: Challenges and Prospects (pp. 133-154). New York : Palgrave Macmillan.

Benhabib, J., Corvalan, A., \& Spiegel, M. M. (2013). Income and democracy: Evidence from nonlinear estimations. Economics Letters, 118(3), 489-492.

Blundell, R., \& Bond, S. (1998). Initial conditions and moment restrictions in dynamic panel data models. Journal of Econometrics, 87(1), 115-143.

Boix, C. (2001). Democracy, development, and the public sector. American Journal of Political Science, $1-17$.

Bologna Pavlik, J. (2018). Corruption: The good, the bad, and the uncertain. Review of Development Economics, 22(1), 311-332.

Bound, J., Jaeger, D. A., \& Baker, R. M. (1995). Problems with instrumental variables estimation when the correlation between the instruments and the endogenous explanatory variable is weak. Journal of the American Statistical Association, 90(430), 443-450.

Brown, D. S., \& Mobarak, A. M. (2009). The transforming power of democracy: regime type and the distribution of electricity. American Political Science Review, 103(2), 193-213.

56 Journal of Leadership, Accountability and Ethics Vol. 16(4) 2019 
Brunetti, A., Kisunko, G., \& Weder, B. (1998). Credibility of rules and economic growth: Evidence from a worldwide survey of the private sector. The World Bank Economic Review, 12(3), 353-384.

Brunetti, A., \& Weder, B. (2003). A free press is bad news for corruption. Journal of Public Economics, 87(7-8), 1801-1824.

Butkiewicz, J. L., \& Yanikkaya, H. (2006). Institutional quality and economic growth: Maintenance of the rule of law or democratic institutions, or both? Economic Modelling, 23(4), 648-661.

Cameron, A. C., \& Trivedi, P. K. (2009). Microeconometrics using stata (Vol. 5). Stata Press College Station, TX.

Campos, N. F., Dimova, R. D., \& Saleh, A. (2010). Whither corruption? A quantitative survey of the literature on corruption and growth.

Canning, D., \& Fay, M. (1993). The effects of transportation networks on economic growth.

Caselli, F., Esquivel, G., \& Lefort, F. (1996). Reopening the convergence debate: a new look at crosscountry growth empirics. Journal of Economic Growth, 1(3), 363-389.

Cerqueti, R., \& Coppier, R. (2011). Economic growth, corruption and tax evasion. Economic Modelling, 28(1), 489-500.

Chowdhury, S. K. (2004). The effect of democracy and press freedom on corruption: an empirical test. Economics Letters, 85(1), 93-101.

Cooray, A. (2009). Government expenditure, governance and economic growth. Comparative Economic Studies, 51(3), 401-418.

Davidson, R., \& MacKinnon, J. G. (2004). Econometric theory and methods (Vol. 5). Oxford University Press New York.

Davoodi, H., \& Tanzi, V. (2002). Corruption, growth, and public finances. In The political economy of corruption (pp. 101-122). Routledge.

Dawson, J. W. (2003). Causality in the freedom-growth relationship. European Journal of Political Economy, 19(3), 479-495.

De Groot, H. L. F., Linders, G., Rietveld, P., \& Subramanian, U. (2004). The institutional determinants of bilateral trade patterns. Kyklos, 57(1), 103-123.

De Long, J. B., \& Shleifer, A. (1993). Princes and merchants: European city growth before the industrial revolution. National Bureau of Economic Research.

Djezou, W. B. (2014). The democracy and economic growth nexus: empirical evidence from cote d'Ivoire. The European Journal of Comparative Economics, 11(2), 251.

Dollar, D., \& Kraay, A. (2002). Growth is Good for the Poor. Journal of Economic Growth, 7(3), 195225.

Dreze, J., \& Sen, A. (1989). Public action for social security: Foundations and strategy.

Drury, A. C., Krieckhaus, J., \& Lusztig, M. (2006). Corruption, democracy, and economic growth. International Political Science Review, 27(2), 121-136.

Easterly, W., \& Levine, R. (1997). Africa's growth tragedy: policies and ethnic divisions. The Quarterly Journal of Economics, 1203-1250. Retrieved from http://qje.oxfordjournals.org/content/112/4/1203.full.pdf

Fayissa, B., \& Nsiah, C. (2013). The impact of governance on economic growth in Africa. The Journal of Developing Areas, 47(1), 91-108.

Fischer, S. (1993). The role of macroeconomic factors in growth. Journal of Monetary Economics, 32(3), 485-512.

Gani, A. (2011). Governance and growth in developing countries. Journal of Economic Issues, 45(1), 1940.

Gerring, J., Thacker, S. C., \& Alfaro, R. (2012). Democracy and human development. The Journal of Politics, 74(1), 1-17.

Gould, D. J., \& Amaro-Reyes, J. A. (1983). The effects of corruption on administrative performance. World Bank Staff Working Paper, 580, 2514.

Gyimah-Brempong, K. (2002). Corruption, economic growth, and income inequality in Africa. Economics of Governance, 3(3), 183-209. 
Hahn, J., \& Hausman, J. (2002). Notes on bias in estimators for simultaneous equation models. Economics Letters, 75(2), 237-241.

Hall, R. E., \& Jones, C. I. (1999). Why do some countries produce so much more output per worker than others? National bureau of economic research.

Heid, B., Langer, J., \& Larch, M. (2012). Income and democracy: Evidence from system GMM estimates. Economics Letters, 116(2), 166-169.

Herzfeld, T., \& Weiss, C. (2003). Corruption and legal (in) effectiveness: an empirical investigation. European Journal of Political Economy, 19(3), 621-632.

Holtz-Eakin, D., Newey, W., \& Rosen, H. S. (1988). Estimating vector autoregressions with panel data. Econometrica: Journal of the Econometric Society, 1371-1395.

Huang, C-J., \& Ho, Y-H. (2017). Governance and economic growth in Asia. North American Journal of Economics and Finance, (39), 260-272.

Huntington, S. P. (1968). Political Order in Changing Societies. New Haven, CT: Yale University Press.

Huynh, K. P., \& Jacho-Chávez, D. T. (2009). Growth and governance: A nonparametric analysis. Journal of Comparative Economics, 37(1), 121-143.

Jalilian, H., Kirkpatrick, C., \& Parker, D. (2006). 2. Creating the conditions for international business expansion: the impact of regulation on economic growth in developing countries-a cross-country analysis. Regulating Development: Evidence from Africa and Latin America, 11.

Kaufmann, D., \& Kraay, A. (2003). Governance and Growth: Causality which way? Evidence for the World, in brief. Manuscript. World Bank Publication.

Kaufmann, D., Kraay, A., \& Zoido-Lobatón, P. (1999). Aggregating governance indicators (Vol. 2195). World Bank publications.

Kaufmann, D., Kraay, A., \& Zoido, P. (2002). Governance matters II: updated indicators for 2000-01. World Bank Policy Research Working Paper, (2772).

Kaufmann, D., \& Wei, S.-J. (1999). Does" grease money" speed up the wheels of commerce? National bureau of economic research.

Khan, M. (2006). Determinants of corruption in developing countries: the limits of conventional economic analysis. International Handbook on the Economics of Corruption, 216-244.

Klitgaard, R. E., \& Klitgaard, R. (1991). Controlling corruption. Univ of California Press.

Knack, S., \& Keefer, P. (1995). Institutions and economic performance: cross-country tests using alternative institutional measures. Economics \& Politics, 7(3), 207-227.

Kumi, E., Yeboah, T., \& Muazu, I. (2015). Greasing or Sanding the Wheels? Effect of Corruption on Economic Growth in sub-Saharan Africa. African Journal of Economic and Sustainable Development.

La Porta, R., Lopez-de-Silanes, F., Shleifer, A., \& Vishny, R. (1999). The quality of government. Journal of Law, Economics, and Organization, 15(1), 222-279.

Lake, D. A., \& Baum, M. A. (2001). The invisible hand of democracy: political control and the provision of public services. Comparative Political Studies, 34(6), 587-621.

Leff, N. H. (1964). Economic development through bureaucratic corruption. American Behavioral Scientist, 8(3), 8-14.

Leys, C. (1965). What is the Problem about Corruption? The Journal of Modern African Studies, 3(02), 215-230.

Lipset, S. M. (1959). Some social requisites of democracy: Economic development and political legitimacy. American Political Science Review, 53(1), 69-105.

Lucas, R. E. (1988). On the mechanics of economic development. Journal of Monetary Economics, 22(1), 3-42.

Lui, F. T. (1985). An equilibrium queuing model of bribery. The Journal of Political Economy, 93(4), 760-781. Retrieved from http://www.jstor.org/stable/pdfplus/1832136.pdf?acceptTC=true

Mankiw, N G. (2000). Principles of Economics (2nd ed.). Fort Worth: Harcourt College Publishers.

Mankiw, N.G., Romer, D., \& Weil, D. N. (1992). A contribution to the empirics of economic growth. National Bureau of Economic Research.

58 Journal of Leadership, Accountability and Ethics Vol. 16(4) 2019 
María-Teresa, M.Ã., Galindo-Martín, M-Á., \& Ribeiro-Soriano, D. (2012). Governance, entrepreneurship and economic growth. Entrepreneurship \& Regional Development, 24(9-10), 865-877.

Mauro, P. (1995). Corruption and Growth. Quarterly Journal of Economics, 110(3), 681-712. https://doi.org/10.2307/2946696

Meltzer, A. H., \& Richard, S. F. (1981). A rational theory of the size of government. Journal of Political Economy, 89(5), 914-927.

Méndez, F., \& Sepúlveda, F. (2006). Corruption, growth and political regimes: cross country evidence. European Journal of Political Economy, 22(1), 82-98. Retrieved from http://ac.elscdn.com/S0176268005000443/1-s2.0-S0176268005000443-main.pdf? tid=5ebb13ae-be36-11e28dbb-00000aacb361\&acdnat=1368715330 4af50bb20c86f9ae3113b928a3f4d7bd

Méon, P.-G., \& Sekkat, K. (2005). Does corruption grease or sand the wheels of growth? Public Choice, 122(1-2), 69-97. Retrieved from http://download.springer.com/static/pdf/415/art\%253A10.1007\%252Fs11127-005-39880.pdf?auth66=1411635019 3f9f1 cdd1d5d0f48349ac3002ad6c1a0\&ext=.pdf

Méon, P-G., \& Weill, L. (2010). Is corruption an efficient grease? World Development, 38(3), 244-259.

Mishra, A. (2010). Corruption and growth: some implications for human development. In Perspectives on corruption and human development (pp. 321-360). Macmillian.

Mo, P. H. (2001). Corruption and economic growth. Journal of Comparative Economics, 29(1), 66-79. Retrieved from http://ac.els-cdn.com/S0147596700917037/1-s2.0-S0147596700917037main.pdf? tid=ba55fafc-cbcf-11e2-804800000aacb360\&acdnat $=1370210562$ f28efc33a2422309f31456f7f70dfb63

Morgan, T. (1964). The theory of error in centrally-directed economic systems. The Quarterly Journal of Economics, 395-419.

Murphy, K. M., Shleifer, A., \& Vishny, R. W. (1990). The allocation of talent: implications for growth. National Bureau of Economic Research.

Myrdal, G. (1968). Asian drama, an inquiry into the poverty of nations. Asian Drama, an Inquiry into the Poverty of Nations.

Nagar, A. L. (1959). The bias and moment matrix of the general k-class estimators of the parameters in simultaneous equations. Econometrica: Journal of the Econometric Society, 575-595.

Narayan, P. K., Narayan, S., \& Smyth, R. (2011). Does democracy facilitate economic growth or does economic growth facilitate democracy? An empirical study of Sub-Saharan Africa. Economic Modelling, 28(3), 900-910.

Nawaz, S. (2015). Growth effects of institutions: A disaggregated analysis. Economic Modelling, 45, $118-126$.

Nelson, R. R., \& Phelps, E. S. (1966). Investment in humans, technological diffusion, and economic growth. The American Economic Review, 56(1/2), 69-75.

Nguyen, T. T., \& Van Dijk, M. A. (2012). Corruption, growth, and governance: Private vs. state-owned firms in Vietnam. Journal of Banking \& Finance, 36(11), 2935-2948.

North, D. (1981). Growth and structural change. New York: Norton.

North, D. (1990). Institutions, Institutional Change, and Economic Performance. Cambridge and London: Cambridge University Press.

Papaioannou, E., \& Siourounis, G. (2008). Democratisation and growth. The Economic Journal, $118(532), 1520-1551$.

Park, J. (2012). Corruption, soundness of the banking sector, and economic growth: A cross-country study. Journal of International Money and Finance, 31(5), 907-929.

Pellegrini, L., \& Gerlagh, R. (2004). Corruption's effect on growth and its transmission channels. Kyklos, 57(3), 429-456.

Persson, T., \& Tabellini, G. (2009). Democratic capital: The nexus of political and economic change. American Economic Journal: Macroeconomics, 1(2), 88-126.

Rigobon, R., \& Rodrik, D. (2005). Rule of law, democracy, openness, and income: Estimating the interrelationships1. Economics of Transition, 13(3), 533-564. 
Rivera-Batiz, F. L. (2002). Democracy, governance, and economic growth: theory and evidence. Review of Development Economics, 6(2), 225-247.

Rodrik, D., \& Wacziarg, R. (2005). Do democratic transitions produce bad economic outcomes? American Economic Review, 95(2), 50-55.

Romer, P. M. (1990). Human capital and growth: theory and evidence. Carnegie-Rochester Conference Series on Public Policy, 32, 251-286. Elsevier.

Roodman, D. (2012). xtabond2: Stata module to extend xtabond dynamic panel data estimator. Statistical Software Components.

Rose-Ackerman, S. (1978). Corruption: A study in political economy. Academic Press New York.

Ross, M. (2006). Is democracy good for the poor? American Journal of Political Science, 50(4), 860-874.

Saha, S., \& Zhang, Z. (2017). Democracy-growth nexus and its interaction effect on human development: A cross-national analysis. Economic Modelling, 63, 304-310.

Shandra, J. M., Nobles, J., London, B., \& Williamson, J. B. (2004). Dependency, democracy, and infant mortality: a quantitative, cross-national analysis of less developed countries. Social Science \& Medicine, 59(2), 321-333.

Shaw, P., Katsaiti, M., \& Jurgilas, M. (2011). Corruption and growth under weak identification. Economic Inquiry, 49(1), 264-275. Retrieved from http://onlinelibrary.wiley.com/store/10.1111/j.1465-7295.2009.00276.x/asset/j.14657295.2009.00276.x.pdf? $\mathrm{v}=1 \& \mathrm{t}=\mathrm{hzig} 8 \mathrm{so} 5 \& \mathrm{~s}=3 \mathrm{cfe} 87 \mathrm{cfb} 9 \mathrm{e} 72095 \mathrm{af57} \mathrm{cb} 21 \mathrm{~b} 8 \mathrm{e} 63 \mathrm{c} 09 \mathrm{fd} 3537 \mathrm{~d} 1$

Shleifer, A., \& Vishny, R. (1993). Corruption 599-618. Quarterly Journal of Economics, (108), 599-618.

Svensson, J. (2005). Eight questions about corruption. The Journal of Economic Perspectives, 19(3), 1942. Retrieved from http://pubs.aeaweb.org/doi/pdfplus/10.1257/089533005774357860

Swaleheen, M. (2011). Economic growth with endogenous corruption: an empirical study. Public Choice, 146(1-2), 23-41. Retrieved from http://downloadv2.springer.com/static/pdf/875/art\%253A10.1007\%252Fs11127-009-95811.pdf?token2 $=\mathrm{exp}=1432411605 \sim \mathrm{acl}=\% 2 \mathrm{Fstatic} \% 2 \mathrm{Fpdf} \% 2 \mathrm{~F} 875 \% 2 \mathrm{Fart} \% 25253 \mathrm{~A} 10.1007 \% 2525$ 2Fs11127-009-95811.pdf* $\sim$ hmac $=855372 \mathrm{c} 67534767 \mathrm{e} 0 \mathrm{~b} 2691127777 \mathrm{f} 904462 \mathrm{~d} 349856 \mathrm{~d} 37 \mathrm{ae} 7 \mathrm{af} 97 \mathrm{ff} 308 \mathrm{~d} 26 \mathrm{c} 316$

Ugur, M. (2014). Corruption's Direct Effects on Per-Capita Income Growth: A Meta-Analysis. Journal of Economic Surveys, 28(3), 472-490.

Vega-Gordillo, M., \& Alvarez-Arce, J. L. (2003). Economic growth and freedom: a causality study. Cato $J ., 23,199$.

Verbeek, M. (2008). A guide to modern econometrics. John Wiley \& Sons.

Wedeman, A. (1997). Looters, rent-scrapers, and dividend-collectors: Corruption and growth in Zaire, South Korea, and the Philippines. The Journal of Developing Areas, 457-478.

Wooldridge, J. (2009). Introduccion a la econometria/Introductory Econometrics: A Modern Approach. Cengage Learning Editores.

You, J.-S., \& Khagram, S. (2005). A comparative study of inequality and corruption. American Sociological Review, 70(1), 136-157. Retrieved from http://asr.sagepub.com/content/70/1/136.full.pdf 